Policy Research Working Paper 4292

\title{
Assessment of the Economic Impacts of Climate Change on Agriculture in Zimbabwe
}

A Ricardian Approach

Reneth Mano

Charles Nhemachena

The World Bank

Development Research Group

Sustainable Rural and Urban Development Team

July 2007 
Policy Research Working Paper 4292

\begin{abstract}
This study uses the Ricardian approach to examine the economic impact of climate change on agriculture in Zimbabwe. Net farm revenue is regressed against various climate, soil, hydrological and socio-economic variables to help determine the factors that influence variability in net farm revenues. The study is based on data from a survey of 700 smallholder farming households interviewed across the country.

The empirical results show that climatic variables (temperature and precipitation) have significant effects on net farm revenues in Zimbabwe. In addition to the analysis of all farms, the study also analyzes the effects on dryland farms and farms with irrigation. The analysis indicates that net farm revenues are affected negatively by increases in temperature and positively by increases in precipitation. The results from sensitivity analysis suggest that agricultural production in Zimbabwe's smallholder farming system is significantly constrained by climatic factors (high temperature and low rainfall). The elasticity results show that the changes in net revenue are high for dryland farming compared to farms with irrigation. The results show that farms with irrigation are more resistant
\end{abstract}

to changes in climate, indicating that irrigation is an important adaptation option to help reduce the impact of further changes in climate.

An overview of farmer adaptation to changing climate indicates that farmers are already using some adaptation strategies — such as dry and early planting, growing drought resistant crops, changing planting dates, and using irrigation - to cushion themselves against further anticipated adverse climatic conditions. An important policy message from the empirical findings is that there is a need to provide adequate extension information services to ensure that farmers receive up-to-date information about rainfall patterns in the forthcoming season so that they make well-informed decisions on their planting dates. Policies that increase farmer training and access to credit and aid facilities and help farmers acquire livestock and other important farm assets can help improve net farm performance. Ensuring the availability and accessibility of fertilizers and crop seeds before the onset of the next cropping season can also significantly improve net farm performance across households.

This paper-a product of the Sustainable Rural and Urban Development Team, Development Research Group—is part of a larger effort in the group to mainstream climate change research. Copies of the paper are available free from the World Bank, 1818 H Street NW, Washington, DC 20433. Please contact Pauline Kokila, room MC3-446, telephone 202-4733716, fax 202-522-1151, email address pkokila@worldbank.org. Policy Research Working Papers are also posted on the Web at http://econ.worldbank.org. The authors may be contacted at rtmano@mweb.co.zw or nhemachenacharles@yahoo. co.uk. July 2007. (41 pages)

The Policy Research Working Paper Series disseminates the findings of work in progress to encourage the exchange of ideas about development issues. An objective of the series is to get the findings out quickly, even if the presentations are less than fully polished. The papers carry the names of the authors and should be cited accordingly. The findings, interpretations, and conclusions expressed in this paper are entirely those of the authors. They do not necessarily represent the views of the International Bank for Reconstruction and Development/World Bank and its affiliated organizations, or those of the Executive Directors of the World Bank or the governments they represent. 


\title{
ASSESSMENT OF THE ECONOMIC IMPACTS OF CLIMATE CHANGE ON AGRICULTURE IN ZIMBABWE: A RICARDIAN APPROACH ${ }^{1}$
}

\author{
Reneth Mano and Charles Nhemachena ${ }^{2}$
}

\footnotetext{
${ }^{1}$ An earlier version of this Working Paper was published as CEEPA Discussion Paper number 11.

2 Respectively, Department of Agricultural Economics \& Extension, University of Zimbabwe; and CEEPA, Department of Agricultural Economics \& Rural Development, University of Pretoria; e-mails: rtmano@mweb.co.zw nhemachenacharles@yahoo.co.uk

This paper was funded by the GEF and the World Bank. It is part of a larger study on the effect of climate change on agriculture in Africa, managed by the World Bank and coordinated by the Centre for Environmental Economics and Policy in Africa (CEEPA), University of Pretoria, South Africa. The authors are grateful to CEEPA for excellence in coordinating Pan African projects of this magnitude; to Dr James Benhin for academic leadership and mentoring; to Prof. Rashid Hassan for useful comments on this report; and to Ms Glwadys Gbetibouo for much assistance. The model underlying this report was developed collaboratively by the authors and the Yale University team, to whom we are grateful for essential training and technical backstopping. We owe an intellectual debt to the Yale team, in particular to Pradeep Kurukulasuriya, whose dedication to our work has greatly inspired us. We are also grateful to the enumerators and drivers who did the field work and assisted with data entry (Ben and Livingstone Chilimanzi, Charity Mudombi, Phillipa Kanyoka, Gerald Chikazunga, Melinda Murandu, Moreblessing Mano and Lyona Madondo); to the AREX district offices and field extension workers whose cooperation and support helped make this project a reality; and particularly to Dr Manzungu and Philip Jindu for much help during data collection in Manicaland and Mashonaland East provinces and to Wellington Jogo for supervising data collection. Special appreciation goes to the University of Zimbabwe agricultural economics staff and graduate students for support and comments at various stages of the research, in particular to Dr Rugube and Dr Sukume and to Unity Chipfupa and Josphat Chisora.
} 



\section{SUMMARY}

This study uses the Ricardian approach to examine the economic impact of climate change on agriculture in Zimbabwe. The approach regresses net farm revenue against various climate, soil, hydrological and socio-economic variables to help determine the factors that influence variability in net farm revenues. The study was based on data from a survey of 700 smallholder farming households interviewed across the country. The temperature and precipitation data came from the Africa Rainfall and Temperature Evaluation System (ARTES) (World Bank 2003) and soil data were obtained from FAO (2003). Data concerning hydrology were obtained from the University of Colorado (Strzepek \& McCluskey 2006).

The empirical results show that climatic variables (temperature and precipitation) have significant effects on net farm revenues in Zimbabwe. In addition to the analysis of all farms, the study also analyzes the effects on rainfed farms and farms with irrigation. Marginal analysis indicates that net farm revenues are affected negatively by increases in temperature and positively by increases in precipitation. The results from sensitivity analysis suggest that agricultural production in Zimbabwe's smallholder farming system is significantly constrained by climatic factors (high temperature and low rainfall). The elasticity results show that the changes in net revenue are very high for rainfed farming compared to farms with irrigation. The elasticities of summer temperature and precipitation for rainfed farms are -7.26 and 12.16, respectively, compared to -3.79 and 9.81 for irrigated farms. The results show that farms with irrigation are more resistant to changes in climate, indicating that irrigation is an important adaptation option to help reduce the impact of further changes in climate.

The study examined some simple climate scenarios to see how agricultural production in the country would respond to climate change. These 'uniform' scenarios assume that only one aspect of climate changes and that change is uniform across the country. The uniform scenarios showed that a $2.5^{\circ} \mathrm{C}$ increase in temperature would result in a decrease in net farm revenues by US $\$ 0.4$ billion for all farms and increase net revenue from farms with irrigation by US $\$ 0.3$ billion. The study also examined the impact of a $5^{\circ} \mathrm{C}$ increase in temperature and the results showed that net revenues would decrease across all farms, rainfed farms and farms with irrigation by US\$0.4 billion, US\$0.5 billion and US $\$ 0.003$ billion respectively. A $7 \%$ and a $14 \%$ decrease in precipitation would result in a decrease in net farm revenue by US $\$ 0.3$ billion for all farms.

The study also examined the impacts of three SRES climate change scenarios, namely CGM2, HadCM3 and PCM. These predicted that by 2100 net farm revenues would decrease across all farms by respectively US $\$ 0.8$ billion, US $\$ 1.3$ billion and US $\$ 1.4$ billion. An overview of farmer adaptation to changing climate indicates that farmers are already using some adaptation strategies - such as dry and early planting, growing drought resistant crops, changing planting dates, and using irrigation - to cushion themselves against further anticipated adverse climatic conditions.

An important policy message from the empirical findings is that there is a great need for the government, through the meteorological department, research and extension, the private sector and NGOS, to provide adequate extension information services to ensure that farmers receive up-to-date information about rainfall patterns in the forthcoming season so that they make well-informed decisions on their planting dates. Another is that the government, research and extension, the private sector and NGOs can improve net farm performances for smallholder farms by ensuring increase farmer training and more access to credit and aid facilities and by helping farmers acquire livestock and important farm assets can improve 
farm performance. Ensuring the availability and accessibility of fertilizers and crop seeds before the onset of the next cropping season can also significantly improve net farm performances across households. 


\section{TABLE OF CONTENTS}

$\begin{array}{lll}\text { Section } & \text { Page }\end{array}$

1 Introduction 5

2 Background information on the country of study - Zimbabwe 6

3 Literature review of empirical models used to assess impacts of 8 climate change on agriculture

4 The Ricardian model specification for Zimbabwe 11

5 Data requirements and sources 13

$6 \quad$ Empirical estimation results and discussions 15

$7 \quad$ Conclusions and insights from the analysis 22

$8 \quad$ Limitations and directions for future research 24

References 26

Appendix A: Spatial rainfall distribution in Zimbabwe 29

Appendix B: Spatial temperature distribution in Zimbabwe 30 


\section{Introduction}

Climate change impact studies have shown that the productivity of agricultural activities is highly sensitive to climate change. The effect of changes in climate on agricultural activities both physical and economic has been shown to be significant for low input farming systems, such as subsistence farming in developing countries in Sub-Saharan Africa that are located in marginal areas and have the least capacity to adapt to changing climatic conditions (Rosenzweig \& Parry 1994; Reilly \& Schimmelpfennig 1999; Kates 2000; McGuigan et al. 2002).

Because most developing countries are heavily dependent on agriculture, the effect of climate change on their productive croplands is likely to threaten economic development and the welfare of the population. In addition, developing countries in tropical regions usually have large areas of poor marginal soils that are unusable for agriculture, which makes them particularly vulnerable to potential damage from environmental changes (Mendelsohn \& Dinar 1999). The importance of agriculture for the economies of most African countries and the farming sector's reliance on the quality of rains during the rainy season make Zimbabwe and other countries in the region particularly sensitive to climate change and food insecure (Mendelsohn et al. 2000).

The effect of climate change on agricultural systems can be seen in the interaction between changes in climate variables and the stresses that result from actions taken to increase agricultural production. Impacts on crop yields, agricultural productivity and food security vary depending on the types of agricultural practices and systems (Watson et al. 1997). There is growing evidence that further increases in global warming leading to changes in main climate variables - temperature, precipitation, sea level rise, atmospheric carbon dioxide content and incidence of extreme events - may significantly affect African agricultural production (Watson et al. 1997), with the result that the livelihoods of subsistence farmers and pastoral peoples, who make up a large portion of rural populations in Sub-Saharan Africa, could be negatively affected. For instance, in areas where temperatures are already warm, such as Zimbabwe and most parts of sub-Saharan Africa, further increases in temperature may actually slow down rather than stimulate plant growth, culminating in a general decrease in expected yield for most of the current food crops. The indirect effect of the increased temperatures is the anticipated reduction in effective rainfall even when current amounts of rainfall are sustained, culminating in greater incidence of crop failure.

Empirical agronomic studies in Zimbabwe have revealed that climate change has a negative effect on the agricultural performance of major crops. For instance Muchena (1994) and Magadza (1994) showed that a $2^{\circ} \mathrm{C}$ rise in ambient temperature and a rise of mean temperature by $4^{\circ} \mathrm{C}$ significantly lowered yields. In another study, Makadho (1996) assessed the potential effects of climate change on corn, using a Global Circulation Model (GCM) and the dynamic crop growth model CERES-maize, and the results indicated that maize production was expected to significantly decrease by approximately $11-17 \%$, under conditions of both irrigation and non-irrigation. A reduced crop growth period because of increases in temperature, particularly during the grain filling and ripening stages, has been found to be the main factor contributing to decreased yields.

There has been extensive research on the impacts of climate change, but little on the economic impacts on agriculture in Zimbabwe. To fill this empirical gap, this study carries out an economic analysis of the potential impacts of climate change on Zimbabwe's agricultural sector at the farm level. It also incorporates a brief analysis of adaptation 
strategies being used by farmers to cushion themselves against changing climatic conditions. The agricultural sector remains the key sector of the economy in Zimbabwe, but agricultural policy making has not yet given enough attention to the impacts of climate change and related issues. The main objective of this study is therefore to develop and apply empirical methods to assess the economic impacts of climate change on agriculture in Zimbabwe.

\subsection{Objectives of the study}

This study followed the general objectives of the Global Environment Facility/World Bank (GEF/WB) Climate Change and African Agriculture Project and redefined them to focus specifically on the Zimbabwe country study. The objectives are:

1. To develop a Ricardian model and quantify the potential economic impacts of climate change on agriculture in Zimbabwe.

2. To predict potential future impacts of anticipated further changes in climatic conditions on Zimbabwe's agricultural sector using the estimated Ricardian model under various simulation scenarios.

3. To identify alternative adaptation measures that Zimbabwean farmers are using to help mitigate potential impacts from anticipated changes in climatic conditions.

4. To inform policy using the empirical results from the study.

\subsection{Outline of the report}

The rest of the report is structured as follows. Section 2 gives the background information about Zimbabwe, Section 3 is a brief literature review of empirical models used to assess economic impacts of climate change, Section 4 specifies the empirical Ricardian model for Zimbabwe, Section 5 presents the data needed for empirical model estimation and the sources, Section 6 discusses the empirical findings, and Sections 7 and 8 present the conclusions from the empirical analysis and discuss directions for future research.

\section{Background information on the country of study - Zimbabwe}

Zimbabwe is a landlocked country in the southern African region, with an area of 390760 square kilometers. It lies within the tropics between $15^{\circ} 30^{\prime} \mathrm{S}$ and $22^{\circ} 30^{\prime} \mathrm{S}$ and $25^{\circ} \mathrm{E}$ and $33^{\circ} \mathrm{E}$. Three broad relief regions are generally recognized on the basis of elevation: the Lowveld (below 900m), the Middleveld (900-1200m), and the Highveld (1200-2000m). In addition, a narrow belt of mountains (2000-2400 m), the Eastern Highlands, runs north to south along the eastern border with Mozambique; and the deep cleft of the Zambezi River Valley forms the boundary with Zambia in the northwest. The climate is largely influenced by relief, as the rainfall increases with altitude. The mean annual rainfall varies from below $400 \mathrm{~mm}$ in the extreme south of the Lowveld to above $2000 \mathrm{~mm}$ on isolated mountain peaks in the Eastern Districts. Middleveld rainfall ranges from $500 \mathrm{~mm}$ to $700 \mathrm{~mm}$ and that of the Highveld from $800 \mathrm{~mm}$ to $1000 \mathrm{~mm}$. Appendices A and B show the spatial distribution of rainfall and temperature in the country. 
The rainfall pattern is distinctly seasonal, with approximately $90 \%$ falling in the six months from 1 October to 31 March. Much of the rain falls as intense tropical downpours and is characterized by its extreme variability in both space and time. Three seasons can be distinguished: a hot and dry spring from mid-September to the onset of the rains, a hot but moist summer covering the rainy season, and a dry winter period consisting of cool nights and warm cloudless days lasting from April to September. The sandy, relatively infertile soils that cover some two-thirds of the country constitute the main soil type in the communal areas. Isolated areas of heavier more fertile soils occur throughout the country, the largest pockets being on the Highveld. Fertile irrigable basaltic vertisols occur extensively in the southern Lowveld.

Agricultural production in Zimbabwe is diverse compared with many tropical countries. Tobacco, maize, cotton and sugar dominate crop production, with wheat, coffee, sorghum, groundnuts, tea, citrus, coffee and vegetables making significantly smaller monetary contributions. Maize dominates crop production, covering more land than all other crops (approx 1.5 million hectares). Tobacco production has steadily increased since 1980. Smallscale communal farmers favor burley tobacco, mainly because it requires less rigorous curing. Rainfed cotton grown in the central and northern parts of the country and under irrigation in the Lowveld supplies the needs of the local textile industry and provides $70 \%$ excess for export. Maize, sorghum and vegetables are the principal subsistence crops. Production for family consumption remains paramount in the majority of peasant farming areas, the dry agro-ecological zones of the country, while increasing quantities of maize and cotton are being marketed from communal areas in the higher rainfall agro-ecological zones. Cotton, sunflowers and groundnuts are the major cash crops for communal farmers. Peasant farmers now produce half the total cotton crop, $75 \%$ of the sunflower and $80 \%$ of the sorghum. Coffee has been promoted as a peasant crop in the Eastern Highlands but production remains small.

As in most developing countries, agriculture and the smallholder farming sector dominate Zimbabwe's economy. Agriculture provides employment and livelihoods for about $70 \%$ of the population, including $30 \%$ of formal employment, and accounts for about $40-50 \%$ of the country's total export revenues. About three-quarters of Zimbabwe's population live in the rural smallholder farming sector and depend on agriculture for their livelihoods). In addition, the agricultural sector contributes about 17\% to the country's GDP (FAO 2005). Agriculture is also an important source of raw materials, providing about $60 \%$ of raw materials for the manufacturing sector in the country (Bautista et al. 2002; Poulton et al. 2002).

\subsection{Observed long-term trends in key climatic variables and growth rate of contribution from agriculture}

The observed long-term trends in key climatic variables (temperature and rainfall) are shown in Figure 1 and the growth rate of GDP contribution from agriculture in Figure 2. As shown in Figure 1, over the years temperatures have been increasing and the rainfall pattern has been highly volatile and varying. It is important to note that there are some correlations between these long-term trends in temperature and rainfall and the growth rate of GDP contribution from agriculture, hunting, forestry and fishing (see Figure 2). For instance, drought years that are depicted by negative rainfall deviation in Figure 2 correspond with the declining and low growth rate in GDP contribution from the agricultural sector, implying that rainfall patterns have a significant effect on this contribution over the years. 
Notable examples are the growth rates in the early 1970s, early 1980s and the 1992 drought. During these drought years the temperature increased and the rainfall was very low, as shown in Figure 1, and this had a significant effect on agricultural performance and hence the growth rate of GDP contribution from the sector. The relationships shown in these graphs suggest it is important to try to quantify the economic effects of climate change on the agricultural sector. We acknowledge the fact that climate change was not the only factor that affected growth rates in GDP contribution of agriculture, as many other factors such as government policies also affected the performance of the sector, but for the purposes of this study we focus on the impacts of climate change.

\section{Literature review of empirical models used to assess impacts of climate change on agriculture}

Three basic approaches have been used to assess the likely economic effects of climate change on agriculture: agro-economic models, agro-ecological zone models and Ricardian cross-sectional models (Mendelsohn \& Dinar 1999).

\subsection{Agronomic-economic models}

This analytical technique make use of well-calibrated crop models from carefully controlled experiments in which crops are grown in field or laboratory settings that simulate different climates and levels of carbon dioxide (Adams et al. 1989, 1990, 1993, 1999; Easterling et al. 1993; Kaiser et al. 1993; Rosenzweig \& Parry 1994; Parry et al. 1999, 2004; Kumar \& Parikh 2001). To ensure that all different outcomes across experimental conditions can be assigned to the variables that are being investigated (temperature, precipitation or carbon dioxide), no variability is allowed in farming methods. In addition, farmer adaptation to changing climate is not included in the estimates from these models. Economic models are then used to predict aggregate crop outputs, prices and net revenue using the yields from the agronomic models (Mendelsohn \& Dinar 1999).

\subsection{Agro-ecological zone analysis}

This approach assigns crops to agro-ecological zones and yields are then predicted (FAO 1996). The agro-ecological models examine changes in agro-ecological zones and crops as the climate changes. This analytical technique make use of well-calibrated crop models from carefully controlled experiments in which crops are grown in field or laboratory settings that simulate different climates and levels of carbon dioxide (Adams et al. 1989, 1990, 1993, 1999; Easterling et al. 1993; Kaiser et al. 1993; Rosenzweig \& Parry 1994; Parry et al. 1999, 2004; Kumar \& Parikh 2001). To ensure that all different outcomes across experimental conditions can be assigned to the variables that are being investigated (temperature, precipitation or carbon dioxide), no variability is allowed in farming methods. In addition, farmer adaptation to changing climate is not included in the estimates from these models. Economic models are then used to predict aggregate crop outputs, prices and net revenue using the yields from the agronomic models (Mendelsohn \& Dinar 1999).

The agro-ecological models, examines changes in agro-ecological zones and crops as climate changes and predict the effect of alternative climate scenarios on crop yields. Economic models then use the yields changes to predict the overall supply and market effects (Darwin et al. 1995). According to Mendelsohn and Dinar (1999), the climate scenarios can be 
relatively simple stories of uniform changes across a country, or they can involve complex geographic distributions of changes. As a result most impact studies examine multiple climate scenarios.

\subsection{The Ricardian cross-sectional approach}

Cross-sectional models measure farm performances across climatic zones (Mendelsohn et al. 1994, 1996; Mendelsohn 2000, Mendelsohn \& Dinar 1999, 2003; Sanghi 1998; Sanghi et al. 1998). The Ricardian approach is the common cross-sectional method that has been used to measure the impact of climate change on agriculture. The method was named after David Ricardo (1772-1823) because of his original observation that land rents would reflect the net productivity of farmland (Mendelsohn \& Dinar 2003). The Ricardian approach has been applied in the United States (Mendelsohn et al. 1994, 1996) and in some developing countries - Brazil (Sanghi 1998), India (Sanghi et al. 1998; Kumar \& Parikh 1998) and South Africa (Gbetibouo \& Hassan 2005) - to examine the sensitivity of agriculture to changes in climate.

The Ricardian approach regresses farm performance (land value or net income) on a set of environmental factors, traditional inputs (land and labor) and support systems (infrastructure) to measure the contribution of each factor to the outcome and detect the effects of long-term climate change on farm values (Mendelsohn et al. 1994, 1996; Mendelsohn \& Dinar 1999). In a well-functioning market system, the value of a parcel of land should reflect its potential profitability, implying that spatial variations in climate derive spatial variations in land uses and in turn land values (Polsky 2004). With this background, it should be possible to estimate a meaningful climate-land value relationship by specifying a multivariate regression model. The estimated coefficients for the climate variables would reflect the economic value of climate to agriculture, holding other factors constant.

The Ricardian cross-sectional approach automatically incorporates farmer adaptation by including adaptations farmers would make to tailor their operations to a changing climate. An important example of farmer adaptation strategies is crop choice where, depending on the effects of warmer climate, a particular crop will be the optimal choice. Optimal crop switching is therefore an important factor to consider when measuring the impact of climate change on agriculture (Mendelsohn et al. 1994, 1996; Mendelsohn \& Dinar 1999). The Ricardian approach provides a framework for making a comparative assessment of 'with' and 'without' adaptation scenarios that can show how adaptation measures may help reduce this impact.

Farmer adaptations that are implicit in the Ricardian model results are projected to largely offset the economic costs associated with climate change (Polsky 2004). Farmers will use available information to their maximum economic benefit in adapting to climatic shocks in any economy at equilibrium. For instance, a standard Ricardian model would imply that if growing citrus crops is more profitable than growing wheat, and if the climate becomes more suitable for citrus than wheat, then those farmers will adapt to the changed climate by drawing on the experiences of citrus farmers elsewhere and switching from wheat to citrus (Polsky 2004).

A criticism of the Ricardian approach is that it fails to fully control for the impact of variables that could also explain the variation in farm incomes. For example, incomplete specification can result in underestimating the damages and overestimating the benefits of climate change (Mendelsohn 2000; Kurukulasuriya \& Rosenthal 2003). Variability in farms is a result of 
many factors besides the effects of climate change. Efforts in the Ricardian studies to control for this problem through including other variables, such as soil quality, market access and solar radiation, are hampered by the difficulty of obtaining perfect measures of these variables (Mendelsohn 2000). The result is that many of these factors may not be taken into account when assessing the impacts on farm revenues. According to Mendelsohn (2000), this is a common problem in developing countries where data is often incomplete. Household labor and animal power are two important variables in many developing country farms that are difficult to control for. The agronomic approach, on the other hand, does not face this problem of extraneous variables as it relies on carefully controlled experiments.

Assuming that prices will remain constant is another limitation of the Ricardian approach (Cline 1996). Mendelsohn et al. (1994), as cited in Kurukulasuriya and Rosenthal (2003), agree that including price effects is problematic and that the Ricardian approach is weaker in that respect. Existing cross-sectional studies rely on a cross section within a country where there is little price variation across farms, with the result that the studies have not been able to estimate the effects of prices. The assumption in the Ricardian studies that prices are constant leads to bias in the welfare calculations (Cline 1996). The cross-sectional approach only measures the loss as producer surplus from the climate change and ignores the price change that would occur if supply changed, and as a result omits consumer surplus from the analysis. The result is that damages are underestimated (omit lost consumer surplus) and benefits are overestimated (overstate value of increased supply) (Mendelsohn 2000). The argument however, is that this also applies to all agro-economic models that are confronted with the same difficulty of predicting domestic price changes when changes in agricultural prices due to climate change are determined at the global level (Kurukulasuriya \& Rosenthal 2003). Despite the failure to address this problem, Mendelsohn et al. (1994) contend that the bias is less than 7\% (Kurukulasuriya \& Rosenthal 2003).

Another limitation of the Ricardian approach is that measuring impact in a static spatial model would only be valid if technology, policy or any other temporally varying factor that would affect land use and farmers' production management decisions does not change, or if the value of alternative uses of the land does not change (Antle 1995). For instance, technological changes would alter the relationship between environmental characteristics and land values and thus the approach would give inaccurate effects of climate change on land values (Antle 1995).

Failure to take account of water supply is another important criticism that has been raised concerning existing cross-sectional models (Darwin 1999; Kurukulasuriya \& Mendelsohn 2006). In examining the effect of country climate on country production the existing models do not take into account water that might come from distant countries through rivers and other water supplies. According to Mendelsohn (2000), there has not been data available predicting the magnitude of these water supplies and how they in turn would be affected by climate change. In addition, the cross-sectional models have not considered the effects from flooding. Integrating water systems into agricultural analysis will be important to all approaches and Mendelsohn and Dinar, (2003) have made a significant contribution by testing the sensitivity of net farm revenues to other sources of water.

Research has shown that agronomic-economic and agro-ecological zone models produce reliable results relating agricultural yield and climate variables. However, these methodologies are complex and have high requirements and they do not incorporate farmers' adaptation strategies to changing climate in their analysis. For the purpose of this study, the modified Ricardian cross-sectional approach, which is simpler and takes into account farmer 
adaptations to changing climate, is adopted to measure the economic impacts of climate change on agriculture in Zimbabwe.

\section{The Ricardian model specification for Zimbabwe}

In the Ricardian model, net revenue or capitalized net revenue (land value $(V)$ ), and not yield, accounts for both the costs and benefits of adaptation. Direct measurement of farm prices or revenues allows the Ricardian approach to account for the direct impacts of climate on yields of different crops as well as the indirect substitution of different activities, and other potential adaptations to different climates (Mendelsohn et al. 1994).

Following Mendelsohn et al. (1994), this study applied the Ricardian approach to measure the effect of climate variables in Zimbabwean agriculture. A number of variables - climatic, soil, socio-economic and hydrological - were examined to determine the intrinsic effect of climate on farmland, as in other Ricardian studies applied elsewhere (Mendelsohn et al. 1994, 1996; Kumar \& Parikh 1998; Sanghi 1998; Sanghi et al. 1998; Mendelsohn \& Dinar 1999, 2003). The farmland value $(V)$, reflects the present value of future net productivity, captured by the following equation (Mendelsohn \& Dinar 2003):

$$
\left.V=\int P_{L E} e^{\delta t} d t=\int\left[\sum P_{i} Q_{i}(X, F, Z, G)-\sum R X\right]\right]^{\delta t} d t
$$

Where $P_{I E}$ is the net revenue per hectare, $P_{i}$ is the market price of crop $i, Q_{i}$ is output of crop $i$, $\mathrm{F}$ is a vector of climate variables, $\mathrm{Z}$ is a set of soil variables, $\mathrm{G}$ is a set of economic variables such as market access, $\mathrm{X}$ is a vector of purchased input prices, $\mathrm{t}$ is time, and $\delta$ is the discount rate.

Assuming a net revenue maximizing farmer, who chooses $\mathrm{X}$, given the characteristics of the farm and market prices, the Ricardian method is a reduced form model of the endogenous variables ( $F, Z$ and $G)$, examining their effect on farm value.

The standard Ricardian model relies on a quadratic formulation of climatic variables:

$$
V=\beta_{0}+\beta_{1} F+\beta_{2} F^{2}+\beta_{3} Z+\beta_{4} G+u
$$

where $u$ is the error term. Equation (2) shows the relationship between farmland value $(V)$ in equation (1) and climate (F), soil (Z) and socio-economic variables $(G)$.

Following Mendelsohn and Dinar (2003), the empirical estimation of the Ricardian model for Zimbabwe extends the standard model given above to thoroughly capture the impact of water on farm value. According to Mendelsohn and Dinar (2003), water was already reflected in the Ricardian model, as it comes to farms in the form of precipitation. However, there are two additional sources of water, surface water and ground water, that can be remote from the farm 
and climate at the farm may give little indication of the amount that is available from these two sources.

To capture these additional sources of water, the empirical model for Zimbabwe introduced runoff as the other source of water $(W)$ in the Ricardian model:

$$
V=\beta_{0}+\beta_{1} F+\beta_{2} F^{2}+\beta_{3} Z+\beta_{4} G+\beta_{5} W+u
$$

where $W$ is a vector of relevant hydrological variables that captures the other sources of water other than precipitation such as surface runoff. Inclusion of $W$ allows for the empirical tests of the relationship between farmland values $(V)$ and other sources of water, such as surface and groundwater. In addition, the study tests the nature of the relationship whether it is linear or quadratic.

Furthermore, the study tests the effect of runoff as the other source of water on climate sensitivity. In this case, the study tries to find out the tolerance of farmers who have access to these additional sources to higher and lower temperatures. Interaction terms between annual climate (F) (normal temperature and precipitation) and mean runoff are added to test this proposition:

$$
V=\beta_{0}+\beta_{1} F+\beta_{2} F^{2}+\beta_{3} Z+\beta_{4} G+\beta_{5} W+\beta_{6} W * F+u
$$

As shown in equation (4), the variable $\left(W^{*} F\right)$ gives the interaction between annual climate and the relevant hydrological variables.

The marginal impact of a climate variable on net farm revenue evaluated at the mean is given by Kurukulasuriya and Mendelsohn (2006):

$E\left[\frac{d V}{d f_{i}}\right]=b_{1, i}+2 * b_{2, i} * E\left[f_{i}\right]$

Welfare changes, $\Delta \mathrm{U}$, as a result of climate change from $T_{i}$ to $T^{*}$ can be measured as follows:

$$
\Delta U=\pi^{*}\left(C_{1}\right)-\pi^{*}\left(C_{0}\right)
$$


Changes in climate that increase net farm income would be beneficial and would be harmful if they lead to decreases in net farm income.

\section{Data requirements and sources}

The data for the analysis is based on a cross-sectional farm household survey conducted in a number of provinces and selected districts across the country. Figure 3 shows the provinces and the number of households sampled in each province. The survey covered most of the country's provinces except two, which were omitted because of budgetary constraints. However, the sampled households give a fair representation of the farming systems in the country. The survey collected data for the 2002/03 and 2003/04 farming seasons for both crop and livestock production activities. It provided information about relevant socioeconomic variables such as farm size, household size, household assets (e.g. plows) and access to extension services, for use in the Ricardian analysis.

The surveyed districts were selected on the basis of agro-climatic and hydrological zones, provincial representation and latitude. The district sample of smallholder rainfed farmers was based on the proportion of district population to the total population of all selected districts. The target sample size was 1000 smallholder households, but because of budgetary constraints and the inaccessibility of some areas only 700 were finally surveyed. Only smallholder farmers were surveyed because former large scale and now resettled areas were not readily accessible. The fact that large scale farms were not included in the sample meant that the study also could not assess the effects of technology on net farm revenues.

The temperature and precipitation data came from Africa Rainfall and Temperature Evaluation System (ARTES) (World Bank 2003). This dataset, created by the National Oceanic and Atmospheric Association's Climate Prediction Center, is based on ground station measurements of precipitation.

Soil data were made available by the Food and Agriculture Organization (FAO 2003). The FAO data provides information about the major and minor soils in each location as well as slope and texture. Data concerning the hydrology was obtained from the University of Colorado (Strzepek \& McCluskey 2006). Using a hydrological model for Africa, the hydrology team calculated flow and runoff for each district.

\subsection{Defining variables}

\subsubsection{Dependent variable}

The absence of well-functioning land markets in Zimbabwe meant that there were no data to estimate land values that reflected the adjustments made by farmers to the normal climate conditions and could be used for estimating the climate response function. This study therefore used farm-level net revenue per hectare (Kumar \& Parikh 2001) as a proxy for the land values. The net revenue per hectare was used as the dependent variable to estimate the climate response function for Zimbabwe.

For this study net revenue is defined as gross revenue less fertilizer and pesticide costs, cost of hired labor (valued at the median market wage rate), cost of transport, packaging and marketing costs, storage costs and post harvest losses. Valuation of both crops and inputs was based on median prices per district. Household labor was excluded from the definition of net farm revenue as it resulted in many households having negative net farm revenues. Bardhan 
and Udry (1999), as cited in Kurukulasuriya and Mendelsohn (2006), reported that in the agricultural development literature, including household labor in net farm revenues is problematic. The net farm revenue is therefore defined without household labor costs and the effect of household labor is controlled for by including household size as an independent variable.

\subsubsection{Explanatory variables}

\section{Climate variables}

Monthly temperature and precipitation data were categorized into four distinct seasons to depict the climatic regimes in Zimbabwe: season 1 - summer, from October to January (ONDJ); season 2 - fall (autumn), from February to April (FMA); season 3 - winter, from May to July (MJJ); and season 4 - spring, August and September (AS). The mean seasonal values of both temperature and precipitation were included in the Ricardian model as well as their quadratic terms. The mean temperatures and precipitation for each season are presented in Table 1.

\section{Hydrological variables}

Mean runoff was included in the Ricardian model as the hydrological variable as well as the interaction terms between mean runoff and each climate variable. This was to test the effect of other water sources on farm net revenues and climate sensitivity (Mendelsohn \& Dinar 2003).

\section{Soil variables}

There is significant variability in soil types across districts and provinces in Zimbabwe. Fiftyfive soil types were available in the data set. The study used correlation analysis between the dependent variables and the soil types and only five soil types were finally included in the final models. The classification of the soils included in the analysis is shown in Table 2.

The main soil types are lithosols, luvisols and chernozems. Lithosols are mainly sandy, rocky and calcareous or siliceous, with salts and gypsum deposits occurring extensively. They are generally very low in inherent fertility and devoid of moisture and vegetation throughout the year. As a result agricultural production on these soils is expected to be low and net returns per unit of land would be limited. Luvisols are usually more fertile and provide a good medium for productive agricultural production for farmers. Chernozems have a relatively high clay content and high organic matter. The texture of these soils is a fairly uniform profile, dark grey to very dark brown to black. They are highly fertile and as such can support crop productivity. Including the soil variable allowed the empirical estimation to capture spatial heterogeneity in net farm revenues across different agro-ecological zones and districts. 


\section{Socio-economic variables}

Socio-economic variables included in the estimation were population density, extension contact, distance from capital city, household size, total cropped area, livestock assets indices, irrigation dummy and dummies for different provinces to capture geographical effects on net farm revenues. The livestock and irrigation variables were included to enable the analysis to assess the importance of livestock and irrigation in helping farmers adapt to changing climatic conditions. The underlying assumption is that further increases in temperature and reductions in rainfall are less favorable for crop production and thus livestock becomes an important option under very stressful conditions.

On the other hand irrigation is an important source of additional water that can support agricultural crop production even during dry spells and drought periods. Access to extension contact was assumed to be an important source of climatic information and hence have a positive relationship with net farm revenues. Household size was used to assess the effect of labor availability on net farm revenue with households with large labor pools assumed to have higher net farm revenues.

Table 3 summarizes all the explanatory variables that were included in the analysis and their expected effects on net revenues given by the expected sign. The positive sign means that the variable is expected to affect net farm revenues positively.

\section{Empirical estimation results and discussions}

This section presents the results and discussions from the empirical estimation of the Ricardian analysis. The section starts by analyzing variability of net farm revenue across provinces and the sampled households to ascertain whether there is any spatial variability in net farm revenues that could be attributed to differences in agro-climatic factors that vary across spatial scales within provinces and the country as a whole. This is followed by a brief overview of the estimation procedure and presentation of the empirical results of the Zimbabwe Ricardian model.

\subsection{Variability in net revenues across households}

A prior expectation was that farm net revenues would vary across spatial scales and in this case across provinces. Because the provinces cover more than one agro-climatic zone they generally exhibit spatial differences in climatic variables and it was therefore expected that this would cause net farm revenues to vary both within provinces and across all the sampled households. Table 4 shows variability in net farm revenue. The results show great variability in net farm revenue within provinces and across the whole sample, indicating that net revenue may be influenced by differences in climatic conditions in the various agro-climatic zones in each province. The empirical analysis therefore tried to find the climatic, soil, socioeconomic and hydrological variables that would help explain this variability. 


\subsection{Empirical model estimation procedure}

The empirical analysis began by estimating the response of net farm revenue $(V)$ (measured as net revenue nr2_3 in equation (1) to climate variables (F) only. The second model added soil variables $(Z)$ to the first model to add spatial heterogeneity in net farm revenues. The third model added socio-economic variables $(G)$ to the second model. The fourth model tested the effect of additional sources of water, in this case runoff, on farm net revenues. The fifth model added the interaction terms between mean annual climate variables (temperature and precipitation) to the fourth model to test whether access to other water supplies affects climate sensitivity.

The Zimbabwe Ricardian model specification assumed a quadratic relationship between net farm revenues and climatic variables to reflect the nonlinear relationship between net farm revenues and climatic variables that is consistent with Ricardian studies applied elsewhere (Mendelsohn et al. 1994, 1996; Kumar \& Parikh 1998; Sanghi 1998; Sanghi et al. 1998; Mendelsohn \& Dinar 1999, 2003). The quadratic term reflects the response function of net revenue as a function of climate variables.

Positive quadratic terms indicate that the net farm revenue function is U-shaped and negative quadratic terms indicate that the function is hill-shaped (Mendelsohn \& Dinar, 2003). The expected relationship between net revenue and temperature based on agronomic research and past cross-sectional analyses is hill-shaped, (Mendelsohn \& Dinar, 2003). The indication from this expectation is that a negative relationship is expected, implying that further increase in temperature would have an adverse effects on net farm revenues and hence agriculture. In addition, the estimation assumed a linear relationship between net farm revenues and other variables (soil, socio-economic and hydrological) that is also consistent with other Ricardian studies such as those mentioned above.

Econometric analysis with cross-sectional data is usually associated with problems of heteroscedasticity and multicollinearity and the effect of outliers in the variables. Although the study did not test for their presence, it was anticipated that these problems would arise in the estimation process. The study therefore used estimation methods that automatically correct for such problems, in this case quantile regression analysis. Though quantile regression analysis basically reduces the weight of outliers on the estimates, it can also be useful for correcting for heteroscedasticity and multicollinearity. Reducing the weight of outliers means that the estimation process reduces the variance of the estimates and hence helps correct for heteroscedasticity. In the estimation process highly correlated variables were dropped because of collinearity.

As a way of ascertaining which model best describes the relationship between net farm revenues and climate, soil, hydrological and socio-economic variables in Zimbabwe, the estimation did several runs of the above models. The study estimated three models for each regression model specification. The first included all the sample farming households, and the other two were rainfed only and households using irrigation. Farming households using irrigation in the study had some areas of rainfed and some areas under irrigation. No farmers exclusively used irrigation alone in their farming activities. The Stata statistical software was used to estimate the models. 


\subsection{Empirical regression analysis results}

Table 5 shows the results of the response of net farm revenues to climate variables only. The linear terms of the summer temperature and precipitation variables are positive and significant. This result is important given that much of agricultural production in Zimbabwe is concentrated in summer; therefore the positive relationship between farm net revenues is beneficial to farmers, particularly the smallholders who rely on rain for their agricultural activities. The linear term of autumn mean precipitation is negative, implying negative effects of increases in precipitation in this season. This season coincides with crop maturity and harvesting when crops do not need any additional rainfall, therefore any increases in this will lead to a significant decrease in farm net revenues as more rain reduces crop yields.

The squared terms for most of the climate variables are significant in all models, which is consistent with the hypothesis that the relationship between climate and net farm revenues is non-linear (Mendelsohn et al. 1994, 1996). The negative quadratic coefficients imply a hillshaped relationship between net revenue and climate variables. The squared mean temperature for summer and squared mean precipitation for summer indicate an inverse quadratic relationship between net revenues and these climate variables. This result implies that increases in summer temperatures and rainfall tend to benefit farm net revenue, with diminishing marginal benefits up to a maximum turning point, after which further increases in these climate variables start to have negative effects on farm net revenues.

The table shows the seasonal climate variables have differential effects across the three models in Table 5. Both linear and squared terms are significant in certain seasons implying that climate has a nonlinear effect on net revenues. The effect of quadratic seasonal climate variables on net farm revenues is not obviously determined by looking at the coefficients, as both the linear and the squared terms play a role (Kurukulasuriya \& Mendelsohn 2006). What can be determined from the sign of the quadratic term is whether the relationship with net farm revenue is hill-shaped or U-shaped if the sign is positive or negative respectively. To determine the effect of the seasonal climate variables on net farm revenue we would need to calculate the marginal impacts of each climate variable being examined.

Table 6 shows the response of net farm revenue to climate and soil variables. Adding soil variables helped capture spatial heterogeneity across the sampled households. These variables positively affected net farm revenues, indicating the importance of spatial variability across the country.

As expected, the lithosols (perci) that are generally very low in inherent fertility and devoid of moisture and vegetation throughout the year had a negative relationship with net farm revenues. The implication is that agricultural production on these soils is expected to be low and net returns per unit of land would be limited. The luvisols (perclcFU, perclfCU, perclgCU) and chernozems (percC_qc1 1a), soils that are usually more fertile and provide a good medium for agricultural production and thus support crop productivity, had a positive and significant relationship with net farm revenues. The soil variables that were included in the model were generally significant in explaining variability mainly in net revenues across households. This shows the importance of controlling for soil types: it brings out more strongly the spatial differential impacts on net farm revenues across different agro-ecological zones and provinces of the country.

The standard Ricardian model results are shown in Table 7. Among the socio-economic variables, more years of education and increased access to extension services are associated with improved farming information that is important for agricultural productivity. The results 
also show that small farms are more productive on per hectare basis than large ones. The possible reason for this observation is that small farms use fixed resources such as household labor and other inputs over a smaller area than large farms. Other important factors that have significant effects on net farm revenues include short distances from the capital, high livestock index and access to irrigation.

One important policy message from this finding is that the government, private sector and NGOs can improve net farm performances for smallholder farms by ensuring increased farmer training and helping farmers acquire more livestock. Another is that because short distances to the capital are important for improving net farm revenues, there is a crucial need to provide easy access to both input and output markets in the country. And because the results show that irrigation and livestock are important factors significantly affecting net farm performances in the country, these two factors can provide a useful channel of farmer adaptation strategy which will help improve net farm revenues in the smallholder farming sector in the face of changing climatic conditions.

The irrigation variable was also significant and positive in explaining the variability of net farm revenues. This result further emphasizes the importance of irrigation as an factor in helping farmers, particularly during the winter season and mid-season dry spells in summer. Farmers with access to irrigation can to cushion themselves against the harsh temperatures and limited rainfall during the dry periods. The important policy message from this finding is that promoting irrigation is very important to help farmers deal with further climate change. For example, the countrywide irrigation program being implemented by the Department of Irrigation in the Office of the President can go a long way to help if it reaches the needy smallholder farmers.

Another point to note is that livestock can be an important source of livelihood for the smallholder farmers. Livestock, particularly cattle, are an important asset in the farming system and can do well in a dry climate. In this case promoting livestock production as a substitute or addition to crop production in dry areas is an important safety net in the face of changing climate in the country. The policy message therefore is that livestock improvement programs instituted by the government's Department of Veterinary Services and private companies are vital for sustaining farming households in the face of changing climate.

The results of the models that estimated the effects of including runoff as an additional source of water are shown in Table 8. They show positive relationships between net farm revenues and runoff as an additional source of water for farms with irrigation and all farms and a negative relationship for rainfed farms. The possible explanation for this is that increases in runoff are more beneficial to farms with irrigation compared to rainfed farms that do not use any runoff. These results are consistent with the expectation that additional water will increase water availability for agricultural activities and augment rainwater in times of seasonal dry spells. In this case additional water sources in the form of runoff can be used as sources of water for irrigation during seasonal dry spells and help improve crop productivity and hence farm net revenues.

Adding interaction terms between mean runoff and climatic variables (temperature and precipitation) did not change the results much. For all farms and rainfed farming, both runoff and the interaction term between runoff and precipitation had a positive sign at the $1 \%$ level of significance. The results indicate that additional sources of water are very important for improving net farm revenue for farmers in the country. 
The results have important policy implications for providing additional water sources to rainfed smallholder agriculture, particularly through irrigation. The government can play an important role in providing additional water sources to farmers through irrigation. On the other hand, for farms with irrigation both the interaction terms were also significant at the $1 \%$ level.

\subsection{Marginal effects of climate variables on net farm revenues}

The study also calculated the marginal impacts of a change in each climate variable (temperature and precipitation), using results from the Standard Ricardian model (Table 7), in order to help interpret the climate coefficients. These values depend on the regression equation that is being used and the climate that is being evaluated. The marginal effect of temperature and precipitation is evaluated at the mean for each sample; for instance, the marginal effect of summer temperature on rainfed is evaluated at the mean temperature of rainfed. Table 8 shows the mean seasonal temperature and precipitation for the sample.

The results shown in Table 9 are based on the results from using coefficients from Table 7 . They indicate that higher summer temperatures have mostly negative effects on net farm revenues, implying that further increases in temperature would be harmful to agricultural activities in the country. A further increase in summer temperature by $1{ }^{\circ} \mathrm{C}$ would reduce net farm revenues by about $\$ 86$ per hectare for all farms and about $\$ 98$ for rainfed farms and $\$ 76$ for farms with irrigation. Increases in the spring temperature also decrease net farm revenues. However, increases in winter and autumn temperatures are beneficial to crops and increase net farm revenues by about $\$ 34$ per hectare for all farms and about $\$ 45$ for rainfed farms and $\$ 69$ for farms with irrigation.

An increase in precipitation has positive effects on net farm revenues, particularly for summer and spring. An increase of one millimeter in summer precipitation would result in an increase in net farm revenues of about $\$ 39, \$ 31$ and $\$ 25$ per hectare for all farms, rainfed farms and farms with irrigation respectively. The increases in winter and autumn precipitation show almost similar results and both have positive effects on net farm revenues. The results points to the importance of more summer rain for successful farming in the country. More rainfall is associated with positive gains in net farm revenues, and the possible explanation for this observation is that there have been recurring droughts in the country since 2000. More rainfall will therefore be crucial for successful farming in most parts of the country.

The elasticity results show that net farm revenues are highly sensitive to changes in climate and the elasticities are relatively high for both summer temperature and precipitation. This is the main cropping season and changes in climate variables in this season have relatively high impacts on net farm revenues compared to the other seasons. It is important also to note that rainfed farms are highly sensitive to changes in temperature and precipitation and they are affected most by these changes as they have relatively high elasticities. 


\subsection{Likely effects of climate change on net farm revenues}

\subsubsection{Uniform climate scenarios}

The study examined the sensitivity of net farm revenues to adverse changes in temperature and rainfall. The changes in net farm revenues as a result of changes in the climatic variables were simulated using the estimated models. The scenarios that were examined included changes in temperature by $2.5^{\circ} \mathrm{C}$ and $5^{\circ} \mathrm{C}$ and decreases in rainfall by $7 \%$ and $14 \%$. The scenarios were based on scenarios used in the study by Kurukulasuriya and Mendelsohn (2006), who estimate the impacts of climate change on African cropland.

Following Kurukulasuriya and Mendelsohn (2006), we used the estimated regression coefficients in Table 7 to examine how changes in climate change net revenue per hectare in each district throughout the country (Equation 6). We then multiplied the change in net revenue per hectare by the number of hectares of cropland in each district to get an aggregate impact for each district. This value was then summed across all the districts of the country to get a total impact for the country:

Aggregate climate impact $\mathrm{d}_{\mathrm{d}}=\operatorname{Sum}\left(\Delta \mathrm{Y}_{\mathrm{i}} * \mathrm{~W}_{\mathrm{j}}\right)$

where $\Delta \mathrm{Yi}=$ change in net revenue per hectare from a climate change

$\mathrm{W}_{\mathrm{j}}=$ hectares of cropland, irrigated cropland or rainfed cropland

$\mathrm{d}=$ district $\mathrm{d}$

The values for cropland were downloaded from FAO statistics (2006). The results of the uniform scenarios are shown in Table 10. These 'uniform' scenarios assume that only one aspect of climate changes and that the change is uniform across the country. They show that a $2.5^{\circ} \mathrm{C}$ increase in temperature would result in a decrease in net farm revenues by US $\$ 0.4$ billion for all farms but increase net revenue for farms with irrigation by US $\$ 0.3$ billion. The study also examined the effect of a $5^{\circ} \mathrm{C}$ increase in temperature and the results show that net revenues would decrease across all farms, rainfed farms and farms with irrigation by US\$0.4 billion, US\$0.5 billion and US\$ 0.003 billion respectively. A 7\% and a 14\% decrease in precipitation would result in a decrease in net farm revenue by US $\$ 0.3$ billion for all farms.

As indicated in Table 10, it is evident that further changes in adverse climate variables (temperature and rainfall) are detrimental to crop production in the country. Rainfed farming is affected most by further increases in temperature and decreases in rainfall. Increases in temperature tend to be beneficial for farms with irrigation, implying that irrigation is important for sustaining agricultural production and as an adaptation option for smallholder farmers. It plays an important role as an additional source of water for crop production, particularly during the dry season and during mid-season dry spells that can affect agricultural production.

With the country having experienced successive droughts since 2000, any further adverse climatic conditions that worsen the already bad conditions would significantly reduce net farm revenues emanating from very low agricultural productivity. The implication from these 
results is that agricultural production in Zimbabwe's smallholder farming system is constrained by climatic factors (high temperature and low rainfall).

\subsubsection{SRES climate scenarios}

The study also examined the effects of a set of climate change scenarios predicted by SRES. Specifically, we used A2 scenarios from the Third Assessment Report (Special Report on Emissions Scenarios - SRES). The SRES scenarios were constructed to explore future developments in the global environment with special reference to the production of greenhouse gases and aerosol precursor emissions (Nakicenovic et al. 2000). After trying a number of scenarios, the study used the models CGM2, HadCM3 and PCM. The predicted climate data for the scenario analysis were provided from the hydrological component of the project from Colorado University.

The predicted climate variables (temperature and precipitation) were used to estimate the expected marginal effects of changes in climate on net farm revenues, based on the estimates from the Ricardian model. Table 11 presents the mean temperature and rainfall predicted by the three models for the years 2050 and 2100. In 2100 CGM2 and HadCM3 predict a $4^{\circ} \mathrm{C}$ and $\mathrm{PCM}$ a $2{ }^{\circ} \mathrm{C}$ increase in temperature in Zimbabwe. Rainfall predictions show that the CGM2 model predicts an average decrease of $10 \%$, the HadCM3 model an average decrease of $17 \%$ and the PCM model an average decrease of $21 \%$ for the year 2100 . However, despite mean rainfall in the country being predicted to increase or decrease depending on the scenario, it in fact varies substantially.

The results for the predicted impacts from the SRES scenarios are presented in Table 12. The scenarios show negative effects on farm net revenues for further increases in temperature, particularly for all farms and rainfed farms. Further increases in temperature would be detrimental to agricultural production in the country for the years 2050 and 2100 . The CGM2, HadCM3 and PCM scenarios predict that by 2100 net farm revenues will decrease by US\$0.8, US\$ 1.3 billion and US\$ 1.4 billion across all farms, rainfed farms and farms with irrigation respectively.

Further reductions in precipitation and increases in temperature in the country predict that farming would not be viable and if farmers are continue to farm there is an urgent need for the government and private institutions to develop ways of helping farmers adapt to these future negative climatic conditions.

These findings show there is a great need for technological development of adaptation packages that are not needed in the present farming conditions but which will be useful for agricultural production by those years. There is therefore a need for investment in research and development so researchers can develop a farming package for smallholder farmers that will enable them to remain in business by the years 2050 and 2100; for instance, one that would include input, irrigation technologies and extension.

\subsection{Farmer strategies to adapt to climate change}

This section briefly reviews adaptation strategies farmers are using to cushion themselves against adverse climatic conditions being experienced in the country. As shown in Figure 4, about $68 \%$ of the farmers in the study indicated that they do at least something in response to 
changing climate, which shows they are aware of the changing climatic conditions. Most use more than one adaptation strategy and most use a number of strategies simultaneously.

The adaptation strategy most commonly used (about $21 \%$ ) is dry and early planting. Farmers therefore need seed varieties that can stay in the soil for some time before the rains, as well as early maturing varieties. They also urgently need easy access to climatic forecasts of the oncoming season. Meteorological and extension information services need to provide farmers with up-to-date information about rainfall patterns in the forthcoming season so that they can make well-informed decisions about planting dates. All this will help ensure that farmers make efficient use of the little rains when they come so their crops can mature within the short wet season and survive the recurrent mid-season droughts.

Other adaptation strategies farmers are using are winter plowing, planting short season varieties, irrigating, and growing drought resistant crops. Winter plowing is very important as it helps conserve moisture, especially when it is done soon after the winter rains. This conserved moisture is important for the success of dry and early planting farming activities that most farmers use as an adaptation strategy. Well-planned winter plowing and water harvesting during the rainy season will be important sources of moisture for successful crop development and growth before the rains. It is therefore important that draft power be accessible and available, to enable farmers to carry out winter plowing in time. The government can help farmers by providing tractors and fuel for tillage, for example through the District Development Fund in the new resettlement areas.

Farmers also indicated that they plant short season and drought resistant crop varieties and practice multiple cropping that includes changing crop mixes. Planting short season and drought resistant crop varieties increases the chances of successful harvests and hence higher net farm revenues despite adverse climatic conditions. Multiple cropping ensures that farmers are able to get some positive net returns from their farming activities: when some crops fail others will produce some positive returns, particularly drought resistant crops such as sorghum.

It is therefore important for plant cultivating companies, research units and the government to make available short season and drought resistant crop varieties that can do well in poor seasons. A typical example is the very short season varieties of maize seed such as SC401, SC403, and medium varieties such as SC501. Farmers need seed varieties to suit their climatic conditions, but in recent seasons there have been shortages of seeds, particularly maize, forcing them to buy whatever is available on the market. The government must ensure that seed varieties are available by promoting and providing conducive environments for seed development in the country and by importing seed to meet the high domestic demand.

Generally agriculture in Zimbabwe has been found to be sensitive to changes in climate, as indicated from the sensitivity analysis above. Farmers plainly need to use adaptation strategies, both short-term (seasonal) and long-term, such as adopting new agricultural technologies to cushion themselves against further anticipated adverse climatic conditions. They need to grow drought tolerant and short season crop varieties that can mature in poor climatic conditions. Other strategies include using support services such as irrigation technologies to augment rainfall and increase production and revenues in the smallholder farming areas. The government, private companies and NGOs must provide support services such as extension and information to help farmers adapt to changing climate. 


\section{Conclusions and insights from the analysis}

The empirical results showed that climatic variables (temperature and precipitation) have significant effects on net farm revenues in Zimbabwe. Net revenues are negatively affected by increases in temperature and decreases in precipitation. The elasticity of summer (the main cropping season) temperature and precipitation on all farms was -4.82 and 15.37 respectively. The study analyzed the effects of climate change on all farms, rainfed farms and farms with irrigation. Marginal analysis showed that changes in temperature and precipitation had very high impacts on net revenues from rainfed farms. The elasticity results showed that the changes in net revenue are very high for rainfed farming compared to farms with irrigation. The elasticity of summer temperature and precipitation for rainfed farms was -7.26 and 12.16 respectively compared to -3.79 and 9.81 for irrigation farms. The results showed that farms with irrigation are more resistant to changes in climate, indicating that irrigation is an important adaptation option for reducing the impacts of further changes in climate.

Among the socio-economic variables, more years of education and increased access to extension services are associated with the improved farming information that is important for agricultural productivity. The results also show that small farms are more productive on a per hectare basis than large farms. The possible reason for this observation is that small farms use fixed resources such as household labor and other inputs over a smaller area than large farms. Other important factors that have significant effects on net farm revenues include short distances from the capital, high livestock index and access to irrigation.

There are important policy messages from these findings. The government, private sector, and NGOs can improve net farm performances for smallholder farms through increasing training for farmers and helping them acquire more livestock. Because short distances to the capital are important in improving net farm revenues, there is a crucial need to provide easy access to both input and output markets in the country to help those who live long distances away. And because irrigation and livestock significantly affect net farm performances in the country, these two factors can be a useful channel for boosting farmer adaptation strategies and improving net farm revenues in the smallholder farming sector in the face of changing climatic conditions.

The irrigation variable was also significant and positive in explaining the variability of net farm revenues. This result further emphasizes the importance of irrigation for helping farmers, particularly during the winter season and mid-season dry spells in summer. Farmers with access to irrigation can cushion themselves against the harsh temperatures and limited rainfall during the dry periods, so promoting irrigation is very important for helping them adapt to further changes in climate. For example, the countrywide irrigation program being implemented by the Department of Irrigation in the Office of the President can go a long way towards helping farmers in the face of further increases in climate if the implementation of the program reaches the needy smallholder farmers in the country.

Another important point to note is that livestock can be another source of livelihood for smallholder farmers. Cattle in particular are an important asset in the farming system and can do well in dry climate. Promoting livestock production as an alternative or complementary option to crop production in dry areas is therefore an important safety net in the face of changing climate in the country. The policy message therefore is that livestock improvement programs by the government's Department of Veterinary Services and private companies are vital for sustaining farming households in the face of changing climate. 
The study also examined some simple climate scenarios to see how agricultural production in the country would respond to climate change. The uniform scenarios showed that a $2.5^{\circ} \mathrm{C}$ increase in temperature would decrease net farm revenues by US $\$ 0.4$ billion for all farms and increase it for farms with irrigation by US $\$ 0.3$ billion. The study also examined the impact of a $5^{\circ} \mathrm{C}$ increase in temperature and the results showed that net revenues would decrease across all farms, rainfed farms and farms with irrigation by US $\$ 0.4$ billion, US $\$ 0.5$ billion and US $\$ 0.003$ billion respectively. A $7 \%$ and a $14 \%$ decrease in precipitation would result in a decrease in net farm revenue by US $\$ 0.3$ billion for all farms. The study also examined the impacts of three SRES climate change scenarios, CGM2, HadCM3 and PCM. These scenarios predicted that by 2100 net farm revenues would decrease by US $\$ 0.8$ billion, US $\$$ 1.3 billion and US\$ 1.4 billion across all farms, rainfed farms and farms with irrigaion respectively.

The study also showed that farmers are already making efforts to adjust to changing climatic conditions $-68 \%$ indicated that they are doing something while only $32 \%$ indicated they are not doing anything. Common adaptation strategies being employed by farmers include dry and early planting, winter plowing, planting short and drought resistant crop varieties and water harvesting. The analysis shows it is important for the government, research units and private companies to invest resources in equipping farmers to help cushion them against further adverse climatic conditions.

The policy message from the empirical findings is that there is great need for the government through the meteorological department, research and extension, private sector and NGOS to provide adequate extension information services to ensure that farmers receive up-to-date information about rainfall patterns in the forthcoming season so that they can make wellinformed decisions about their planting dates. Another important policy message is that the government, research and extension, private sector and NGOs can improve net farm performances for smallholder farms by ensuring increased farmer training, increasing access to credit and aid facilities, and helping farmers acquire livestock and other farm assets. Furthermore, ensuring the availability and accessibility of fertilizers and crop seeds before the onset of the next cropping season can significantly improve net farm performances.

\section{Limitations and directions for future research}

The empirical findings in this study are based on aggregate district level cross-sectional data and need to be treated with some caution since important farm-level decision making and other important variables that affect net farm revenues may have been missed. It is therefore important for future research to focus on the micro-level analysis of the impacts of climate on net farm revenues. In addition the study focused on smallholder farming households and it is important for future research to consider the commercial large scale sector comprising the new resettlement areas that have high level technology and irrigation facilities. This would enable the analysis to capture the impacts of technology and irrigation on net farm revenues.

Furthermore, this study quantified the economic impacts of climate change using the Ricardian approach but did not analyze any welfare effects of climate change. Future research should analyze the effect of climate change on the welfare of farm households and the country as a whole. In addition, it would be important to do regional analysis of the impacts of climate change in addition to the country level analysis. 
Although this study said a little about the adaptation options farmers are using to cushion themselves against changing climatic conditions, it did not go further and analyze farmer behavior. It is therefore also important for future research to consider micro-level analysis of adaptation strategies, using farmer behavioral models to study how farmers make decisions when choosing among various adaptation options. 


\section{REFERENCES}

Adams RM, Glyer D \& McCarl BA, 1989. The economic effects of climate change in US agriculture: A preliminary assessment. In Tirpak D \& Smith J (eds), The potential effects of global climate change in the United States: Report to congress. EPA 23005-89-050, Washington DC: United States Environmental Protection Agency.

Adams RM, Fleming RA, Chang C, McCarl BA \& Rosenzweig C, 1993. A reassessment of the economic effects of global climate in US agriculture. US Environmental Protection Agency, Washington DC.

Adams RM et al., 1990. Global climate change and US agriculture. Nature 345: 219-224.

Adams RM et al., 1999. The economic effects of climate change on US agriculture. In Mendelsohn R \& Neumann J (eds), The economic impact of climate on the economy of the United States. Cambridge UK: Cambridge University Press.

Antle JM, 1995. Climate change and agriculture in developing countries. American Journal of Agricultural Economics 77: 741-746.

Bardhan P \& Udry C, 1999. Chapter 4. Development Economics. Oxford: Oxford University Press.

Bautista RM, Thomas M, Muir-Leresche K \& Lofgren H, 2002. Macroeconomic policy reforms and agriculture: Towards equitable growth in Zimbabwe. Research Report 128, IFPRI (International Food Policy Research Institute) Washington DC. http://www.ifpri.org/pubs/abstract/128/rr128.pdf

Cline WR, 1996. The impact of global warming on agriculture: Comment. American Economic Review 86: 1309-1312.

Darwin R, 1999. The impacts of global warming on agriculture: A Ricardian analysis: Comment. American Economic Review 89: 1049-1052.

Darwin R, Tigras M, Lewandrowski J \& Raneses A, 1995. World agriculture and climate change: Economic adaptations. AER-703, US Department of Agriculture, Economic Research Service, Washington DC.

Easterling WE et al., 1993. Agricultural impacts and responses to climate change in the Missouri-Iowa-Nebraska-Kansas MINK region. Climatic Change 24: 23-61.

FAO (Food and Agriculture Organization of the United Nations), 1996. Agro-ecological zoning: Guidelines. FAO Soils Bulletin 73. Rome, Italy.

FAO (Food and Agriculture Organization), 2003. The digital soil map of the world: Version 3.6 (January), Rome, Italy.

FAO (Food and Agriculture Organization), 2005. FAOSTAT. http://www.fao.org/ag/agl/aglw/aquastat/countries/zimbabwe/index.stm

FAOSTAT, 2006. Estimates of agricultural land use. Internet database, Rome, Italy. 
Gbetibouo G \& Hassan R, 2005. Economic impact of climate change on major South African field crops: A Ricardian approach. Global and Planetary Change 47: 143-152.

Kaiser HM, Riha SJ, Wilks DS, Rossiter DG \& Sampath RK, 1993b. A farm-level analysis of economic and agronomic impacts of gradual warming. American Journal of Agricultural Economics 75: 387-398.

Kates RW, 2000. Cautionary tales: Adaptation and the global poor. Climatic Change 45: 517.

Kumar K \& Parikh J, 1998. Climate change impacts on Indian agriculture: The Ricardian approach. In Dinar A et al. (eds), 1998. Measuring the Impact of Climate Change on Indian Agriculture. World Bank Technical paper 402. Washington, DC.

Kumar K \& Parikh J, 2001. Socio-economic impacts of climate change on Indian agriculture. International Review for Environmental Strategies 2(2).

Kurukulasuriya P \& Mendelsohn R, 2006. A Ricardian analysis of the impact of climate change on African cropland. CEEPA Discussion Paper No. 8, Centre for Environmental Economics and Policy in Africa, University of Pretoria.

Kurukulasuriya P \& Rosenthal S, 2003. Climate change and agriculture: A review of impacts and adaptations. Paper No. 91 in Climate Change Series, Agriculture and Rural Development Department and Environment Department, World Bank, Washington, DC.

Magadza CHD, 1994. Climate change: Some likely multiple impacts in Southern Africa, Food Policy 19(2): 165-191.

Makadho JM, 1996. Potential effects of climate change on corn production in Zimbabwe. Climate Research 6(2): 147-151.

McGuigan C, Reynolds R \& Wiedmer D, 2002. Poverty and climate change: Assessing impacts in developing countries and the initiatives of the international community. London School of Economics Consultancy Project for the Overseas Development Institute.

Mendelsohn R, 2000. Measuring the effect of climate change on developing country agriculture. Two essays on climate change and agriculture: A developing country perspective. FAO economic and social development paper 145.

Mendelsohn R \& Dinar A, 1999. Climate change, agriculture, and developing countries: Does adaptation matter? The World Bank Research Observer 14: 277-293.

Mendelsohn R \& Dinar A, 2003. Climate, water, and agriculture. Land Economics 79(3): 328-341.

Mendelsohn R, Dinar A \& Dalfelt A, 2000. Climate change impacts on African agriculture. http://www.ceepa.co.za/Climate_Change/pdf/(5-22-01)afrbckgrnd-impact.pdf

Mendelsohn R, Nordhaus W \& Shaw D, 1994. The impact of global warming on agriculture: A Ricardian analysis. American Economic Review 84: 753-771. 
Mendelsohn R, Nordhaus W \& Shaw D, 1996. Climate impacts on aggregate farm values: Accounting for adaptation. Agriculture and Forest Meteorology 80: 55-67.

Muchena P, 1994. Implication of climate change for maize yields in Zimbabwe. In Rosenzweig C \& Iglesias A (eds), Implications of climate change for international agriculture: Crop modeling study. (EPA 230-B-94-003). US Environmental Protection Agency, Washington DC.

Nakicenovic N et al, 2000. Special Report on Emissions Scenarios: A special report of Working Group III of the Intergovernmental Panel on Climate Change, Cambridge University Press, Cambridge, UK. http://www.grida.no/climate/ipcc/emission/index.htm

Parry ML, Rosenzweig C, Iglesias A, Fischere G \& Livermore M, 1999. Climate change and world food security: A new assessment. Global Environmental Change 9: S51-S67

Parry ML, Rosenzweig C, Iglesias A, Livermore M \& Fischere G, 2004. Effects of climate change on global food production under SRES emissions and socio-economic scenarios. Global Environmental Change 14: 53-67.

Polsky C, 2004. Putting space and time in Ricardian climate change impact studies: Agriculture in the US great plains, 1969-1992. Annals of the Association of American Geographers 94(3): 549-564.

Poulton C, Davies R, Matshe I \& Urey I, 2002. A review of Zimbabwe's agricultural economic policies: 1980-2000. http://www.imperial.ac.uk/agriculturalsciences/research/sections/aebm/projects/poor ag_downloads/zimagback.pdf

Reilly J \& Schimmelpfennig D, 1999. Agricultural impact assessment, vulnerability, and the scope for adaptation. Climatic Change 43: 745-788.

Rosenzweig C \& Parry ML, 1994. Potential impact of climate change on world food supply. Nature 367: 133-138.

Sanghi A, 1998. Global warming and climate sensitivity: Brazilian and Indian agriculture. $\mathrm{PhD}$ Dissertation. Department of Economics, University of Chicago.

Sanghi A, Mendelsohn R \& Dinar A, 1998. The climate sensitivity of Indian agriculture. In Dinar A et al. (eds), 1998. Measuring the impact of climate change on Indian agriculture. World Bank Technical Paper 402. World Bank, Washington, DC.

Strzepek K \& McCluskey A, 2006. District level hydroclimatic time series and scenario analysis to assess the impacts of climate change on regional water resources and agriculture in Africa. CEEPA Discussion Paper No 13, Centre for Environmental Economics and Policy in Africa, University of Pretoria.

Watson RT, Zinyoera MC \& Moss RH, 1997. The regional impacts of climate change: An assessment of vulnerability. A special report of the IPCC Working Group II. Cambridge: Cambridge University Press.

World Bank, 2003. Africa Rainfall and Temperature Evaluation System. World Bank, Washington DC. 


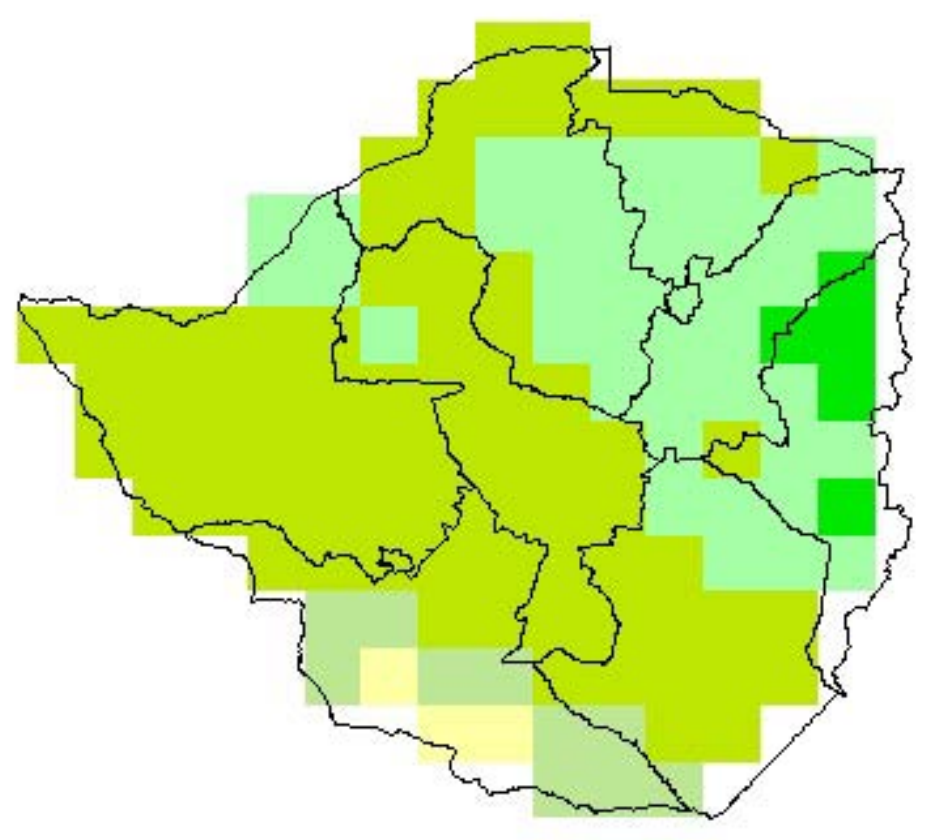

Precipitation av. $\mathbf{m m} / \mathbf{y e a r}$

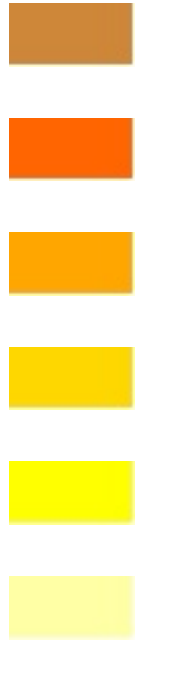

$0-24$

$25-74$

$75-124$

$125-224$

$225-274$

$275-374$

$375-474$

$475-724$

Source: http://www.iiasa.ac.at/Research/LUC/GAEZ/index.htm

$725-974$

Derived from FAO (2000). Data averaged over a period of 37 years.

\begin{tabular}{|l|l}
\hline & $975-1474$ \\
& $1475-2474$ \\
& $2475-4974$ \\
& $4975-7474$ \\
\hline & $7475-10004$ \\
\hline & $>10005$ \\
\hline & No Data
\end{tabular}


Temperature (av. annual ${ }^{\circ} \mathrm{C}$ )
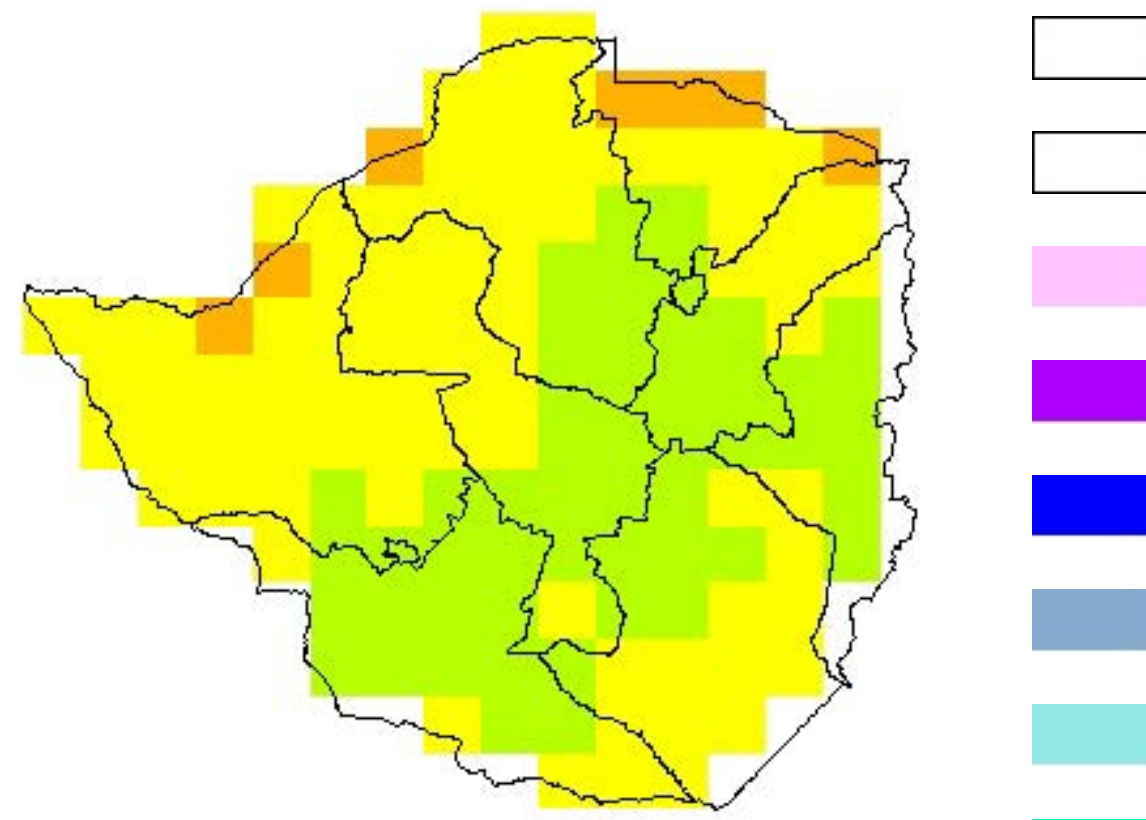

$<-29.5$

-29.5 to -25

-24.5 to -15.0

-14.5 to -10.0

-9.5 to -5.0

-4.5 to 0.0

0.5 to 5.0

5.5 to 10.0

10.5 to 15.0

15.5 to 20.0

20.5 to 30.0

30.5 to 35.0

35.5 to 40.0

http://www.fao.org/WAICENT/FAOINFO/SUSTDEV/EIdir ect/climate/EIsp0001.htm

$>40.0$

Dataset averaged over a period of 37 years, based on Leemans \& Cramer (1991)

No Data 
Table 1: Temperature $\left({ }^{\circ} \mathrm{C}\right)$ and precipitation $(\mathrm{mm} / \mathrm{mo})$ normals (sample mean)

\begin{tabular}{lllc}
\hline Temperature & Mean & Precipitation & Mean \\
\hline summer_temp & 22.48 & summer_precip & 138.37 \\
autum_temp & 20.63 & autum_precip & 89.35 \\
winter_temp & 16.52 & winter_precip & 7.45 \\
spring_temp & 21.23 & spring_precip & 15.48 \\
\hline
\end{tabular}

Table 2: Classification of soils included in the analysis

\begin{tabular}{lll}
\hline Soil type & Soil main category & Soil sub-category \\
\hline Perci & Lithosols & \\
perclcFU & Luvisols & Chromic luvisols \\
perclfCU & Luvisols & Ferric luvisols \\
perclgCU & Luvisols & Gleyic luvisols \\
percC_qc1 1a & Chernozems & \\
\hline
\end{tabular}


Table 3: Explanatory variables included in the empirical analysis

\begin{tabular}{|c|c|c|}
\hline & Variable description & Expected sign \\
\hline summer_temp & Mean temperature in summer in $\left({ }^{\circ} \mathrm{C}\right)$ & \pm \\
\hline autum_temp & Mean temperature in autumn in $\left({ }^{\circ} \mathrm{C}\right)$ & \pm \\
\hline winter_temp & Mean temperature in winter in $\left({ }^{\circ} \mathrm{C}\right)$ & \pm \\
\hline spring_temp & Mean temperature in spring in $\left({ }^{\circ} \mathrm{C}\right)$ & \pm \\
\hline summer_tempsq & Mean summer temperature in $\left({ }^{\circ} \mathrm{C}\right)$ squared & \pm \\
\hline autum_tempsq & Mean autumn temperature in $\left({ }^{\circ} \mathrm{C}\right)$ squared & \pm \\
\hline winter_tempsq & Mean winter temperature in $\left({ }^{\circ} \mathrm{C}\right)$ squared & \pm \\
\hline spring_tempsq & Mean spring temperature in $\left({ }^{\circ} \mathrm{C}\right)$ squared & \pm \\
\hline summer_precip & Mean precipitation in summer & \pm \\
\hline autum_precip & Mean precipitation in autumn & \pm \\
\hline winter_precip & Mean precipitation in winter & \pm \\
\hline spring_precip & Mean precipitation in spring & \pm \\
\hline summer_precipsq & Mean precipitation in summer squared & \pm \\
\hline autum_precipsq & Mean precipitation in autumn squared & \pm \\
\hline winter_precipsq & Mean precipitation in winter squared & \pm \\
\hline spring_precipsq & Mean precipitation in spring squared & \pm \\
\hline Perci & Soil type Perci & \pm \\
\hline perclcFU & Soil type perclcFU & \pm \\
\hline perclfCU & Soil type perclfCU & \pm \\
\hline perclgCU & Soil type perclgCU & \pm \\
\hline percC_qc1 1a & Soil type percC_qc1 1a & \pm \\
\hline Population_density & Population density per province & \pm \\
\hline Extension_contact & Contact with extension agents & + \\
\hline Household_size & Household size & \pm \\
\hline Education_years_head & Number of education years of household head & + \\
\hline Total_cropped_area & Total cropped area & \pm \\
\hline Distance_capital & Distance of district from capital city & - \\
\hline Livestock_index & Livestock asset index & + \\
\hline Irrigation $(1 / 0)$ & Irrigation dummy & + \\
\hline Runoff_mean & Mean runoff & + \\
\hline Temp_Runoff_mean & Interaction term between mean annual temperature and mean runoff & + \\
\hline Precip_Runoff_mean & Interaction term between mean annual wetness index and mean runoff & + \\
\hline
\end{tabular}


Table 4: Variability in net farm revenue across provinces and the whole sample (US\$/ha)

\begin{tabular}{lcc}
\hline Province & Mean net farm revenue & Range \\
\hline Manicaland & 281.31 & 2094.95 \\
Mashonaland Central & 915.23 & 5036.57 \\
Mashonaland East & 499.93 & 2769.09 \\
Mashonaland West & 240.23 & 1879.34 \\
Masvingo & 231.71 & 2744.46 \\
Midlands & 375.13 & 2665.44 \\
Total sample & 355.89 & 5859.27 \\
\hline
\end{tabular}

Table 5: Model 1 - Response of farm net revenue to climate variables only

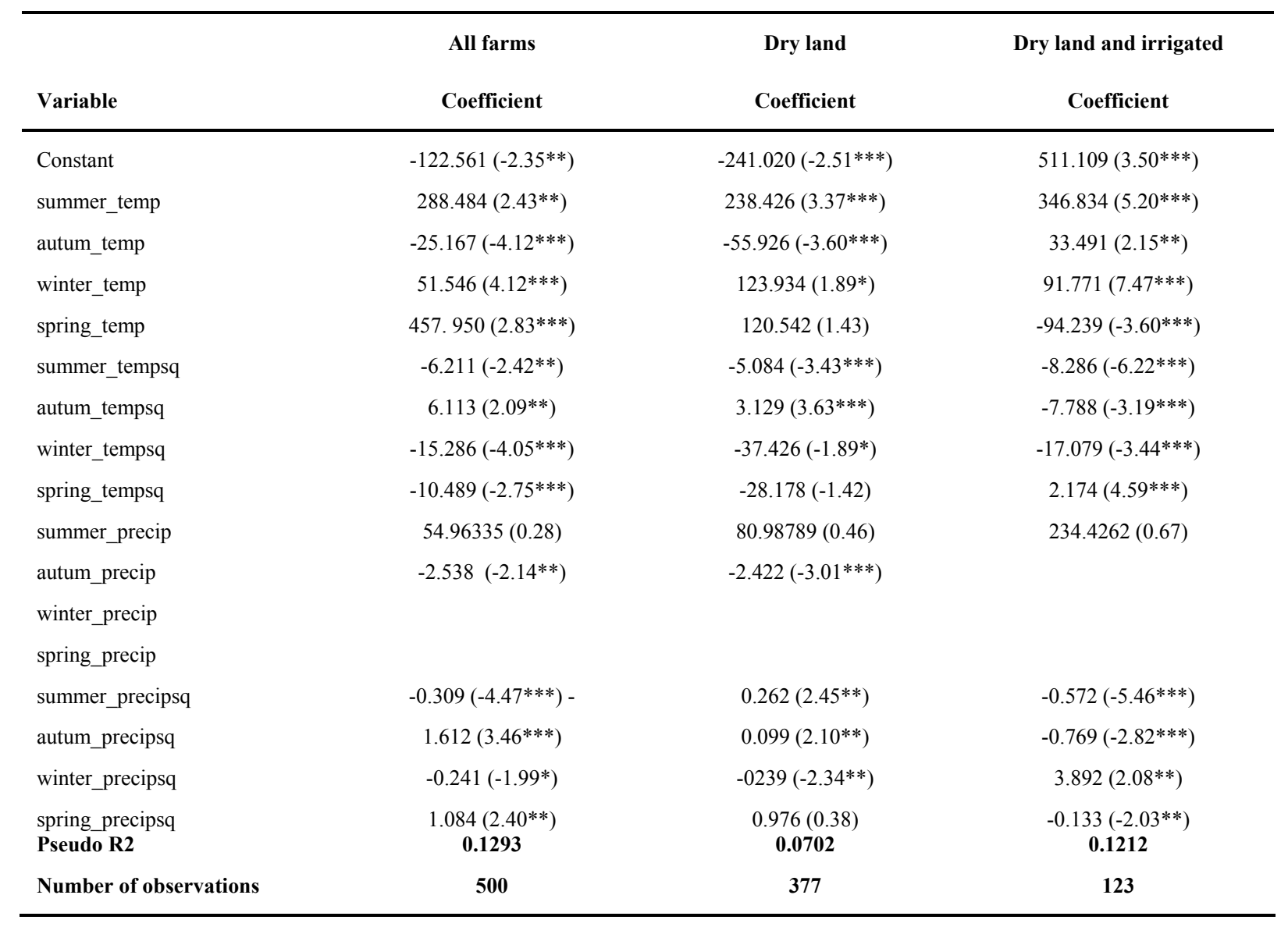

$*$ significant at $10 \%$ level $* *$ significant at $5 \%$ level $* * *$ significant at $1 \%$ level 
Table 6: Model 2 - Response of farm net revenue to climate and soil variables

\begin{tabular}{|c|c|c|c|}
\hline & All farms & Dry land & Dry land and irrigated \\
\hline Variable & Coefficient & Coefficient & Coefficient \\
\hline Constant & $119.438(7.39 * * *)$ & $546.961(4.17 * * *)$ & $-632.430(-5.64 * * *)$ \\
\hline summer_temp & $179.998\left(1.64^{*}\right)$ & $150.605(2.00 * *)$ & $-112.028(-0.83)$ \\
\hline autum_temp & $-129.609\left(-2.10^{* *}\right)$ & $-143.617(-1.83 *)$ & \\
\hline winter_temp & $125.501(10.42 * * *)$ & $78.587(3.08 * * *)$ & $120.329(0.74)$ \\
\hline \multicolumn{4}{|l|}{ spring_temp } \\
\hline summer_tempsq & $-4.589(-1.63 *)$ & $-3.261(-2.04 * *)$ & $-2.989(-0.86)$ \\
\hline autum_tempsq & $20.123\left(5.10^{* * *}\right)$ & $39.637\left(1.86^{*}\right)$ & $-45.108(-3.48 * * *)$ \\
\hline winter_tempsq & $-6.365(-9.92 * * *)$ & $-24.234(-2.79 * *)$ & $-35.013(-2.67 * * *)$ \\
\hline spring_tempsq & $41.295(7.06 * * *)$ & $-6.526(-1.70 *)$ & $11.841(6.23 * * *)$ \\
\hline summer_precip & $28.262\left(4.16^{* * *}\right)$ & $48.213\left(2.55^{* *}\right)$ & $14.560\left(1.86^{*}\right)$ \\
\hline autum_precip & $-160.7166(-2.77 * *)$ & $490.1056(2.33 * *)$ & \\
\hline \multicolumn{4}{|l|}{ winter_precip } \\
\hline \multicolumn{4}{|l|}{ spring_precip } \\
\hline summer_precipsq & $-0.007(-3.02 * * *)$ & $-1.471(-2.99 * * *)$ & $-3.916(-3.83 * * *)$ \\
\hline autum_precipsq & $1.120\left(4.19^{* * *}\right)$ & $-2.068(-2.79 * *)$ & $-3.485(-1.97 *)$ \\
\hline winter_precipsq & $-14.256(-2.96 * * *)$ & $-19.622(-1.01)$ & $1.647(1.95 *)$ \\
\hline spring_precipsq & $6.611(1.15)$ & $6.947(0.95)$ & $-8.276(-0.94)$ \\
\hline perci & $-632.217(-2.37 * *)$ & $-1457.065(-1.34)$ & $-471.833(-0.67)$ \\
\hline perclcFU & $44.4282(-2.67 * *)$ & $1680.484(3.96 * * *)$ & $1142.162(2.23 * *)$ \\
\hline perclfCU & $232.464\left(6.36^{* * *}\right)$ & $667.719(4.23 * * *)$ & \\
\hline perclgCU & $117.438\left(4.18^{* * *}\right)$ & $935.872(2.09 * *)$ & $126.247(4.64 * * *)$ \\
\hline percC_qc1 1a & $243.978(2.50 * *)$ & $1946.999(2.24 * *)$ & $889.149\left(1.85^{*}\right)$ \\
\hline Pseudo R2 & 0.1384 & 0.0999 & 0.1295 \\
\hline Number of observations & 500 & 377 & 123 \\
\hline
\end{tabular}

* significant at $10 \%$ level $* *$ significant at $5 \%$ level $* * *$ significant at $1 \%$ level 
Table 7: Model 3 - Response of farm net revenue to climate, soil and socio-economic variables

\begin{tabular}{|c|c|c|c|}
\hline & All farms & Dry land & Dry land and irrigated \\
\hline Variable & Coefficient & Coefficient & Coefficient \\
\hline Constant & $809.559(3.61 * * *)$ & $1050.436\left(6.59^{* * *}\right)$ & $-356.491(-4.22 * * *)$ \\
\hline summer_temp & $-27.647(-3.11 * * *)$ & $-39.124\left(-2.05^{* *}\right)$ & $-15.212(-6.54 * * *)$ \\
\hline autum_temp & $-94.305(-1.24)$ & $-108.713(-2.53 * *)$ & \\
\hline winter_temp & $83.012\left(4.79^{* * *}\right)$ & $122.861\left(2.77^{* *}\right)$ & $254.331(3.35 * * *)$ \\
\hline \multicolumn{4}{|l|}{ spring_temp } \\
\hline summer_tempsq & $-1.083(-3.17 * * *)$ & $-1.317(-2.14 * *)$ & $-1.591(-6.56 * * *)$ \\
\hline autum_tempsq & $3.232(2.24 * *)$ & $3.420\left(2.57^{* *}\right)$ & $1.049\left(4.88^{* * *}\right)$ \\
\hline winter_tempsq & $-1.481(-5.02 * * *)$ & $-2.343\left(-3.03^{* *}\right)$ & $-5.608\left(-3.16^{* * *}\right)$ \\
\hline spring_tempsq & $-1.042\left(-1.76^{*}\right)$ & $-1.186\left(1.60^{*}\right)$ & $-1.301\left(-2.15^{* *}\right)$ \\
\hline summer_precip & $263.981(2.50 * *)$ & $146.694(1.77 *)$ & $135.076(7.87 * * *)$ \\
\hline autum_precip & $-5.197(-3.67 * * *)$ & $-6.355\left(-2.13^{* *}\right)$ & \\
\hline \multicolumn{4}{|l|}{ winter_precip } \\
\hline \multicolumn{4}{|l|}{ spring_precip } \\
\hline summer_precipsq & $-0.811(-2.24 * *)$ & $-0.417(-4.54 * * *)$ & $-0.397(-6.54 * * *)$ \\
\hline autum_precipsq & $0.202\left(3.49^{* * *}\right)$ & $0.160(1.81 *)$ & $0.122(9.11 * * *)$ \\
\hline winter_precipsq & $1.548(1.37)$ & $1.631\left(1.96^{*}\right)$ & $1.392(8.22 * * *)$ \\
\hline spring_precipsq & $-1.221(-1.08)$ & $-1.026\left(-1.85^{*}\right)$ & $-1.109(-8.00 * * *)$ \\
\hline perci & $-1023.718(-2.61 * *)$ & $-859.403\left(-1.78^{*}\right)$ & \\
\hline perclcFU & $105.639(3.97 * * *)$ & $429.295(2.29 * *)$ & $221.024(6.24 * * *)$ \\
\hline perclfCU & $1264.994\left(2.16^{* *}\right)$ & $294.798\left(1.96^{*}\right)$ & \\
\hline perclgCU & $1029.376\left(2.69^{* * *}\right)$ & $338.8254(4.64 * * *)$ & \\
\hline percC_qc1 1a & $262.422(1.70 *)$ & $145.679\left(2.16^{* *}\right)$ & \\
\hline Population_density & $9.726(0.93)$ & $-1.05\left(-1.76^{*}\right)$ & $-0.093(-1.54)$ \\
\hline Extension_contact & $2.869\left(5.14^{* * *}\right)$ & $154.764(3.03 * * *)$ & $600.641(6.99 * * *)$ \\
\hline Household_size & $21.805\left(2.98^{* * *}\right)$ & $14.539(1.37)$ & $52.854(6.77 * * *)$ \\
\hline Education_years_head & $12.96162(3.47 * * *)$ & $12.718(2.38 * *)$ & $30.532\left(7.13^{* * *}\right)$ \\
\hline Total_cropped_area & $-80.653(-15.02 * * *)$ & $-84.623(-11.12 * * *)$ & $-58.784(-8.31 * * *)$ \\
\hline Distance_capital & $-13.964\left(-2.30^{* *}\right)$ & $-22.107(-1.81 *)$ & $-29.411(-2.79 * *)$ \\
\hline Livestock_index & $4.234(10.62 * * *)$ & $4.892(6.83 * * *)$ & $3.271(9.56 * * *)$ \\
\hline Irrigation $(1 / 0)$ & $110.737(2.89 * * *)$ & & \\
\hline Pseudo R2 & 0.1871 & 0.2312 & 0.2458 \\
\hline Number of observations & 500 & 377 & 123 \\
\hline
\end{tabular}

$*$ significant at $10 \%$ level $* *$ significant at $5 \%$ level $* * *$ significant at $1 \%$ level 
Table 8: Model 4 - Response of farm net revenue to climate, soil and socio-economic variables and other sources of water (runoff)

\begin{tabular}{|c|c|c|c|}
\hline Variable & $\begin{array}{l}\text { All farms } \\
\text { Coefficient }\end{array}$ & $\begin{array}{l}\text { Dry land } \\
\text { Coefficient }\end{array}$ & $\begin{array}{c}\text { Dry land and irrigated } \\
\text { Coefficient }\end{array}$ \\
\hline Constant & $691.789\left(3.95^{* * *}\right)$ & $124.311\left(6.27^{* * *}\right)$ & $990.598(1.87 *)$ \\
\hline summer_temp & $-149.014(2.39 * *)$ & $-119.925(1.94 * *)$ & $-105.513(-9.07 * * *)$ \\
\hline autum_temp & $-30.493(-2.62 * *)$ & $-269.205(-2.00 * *)$ & \\
\hline winter_temp & $27.076(1.01)$ & $18.443(0.46)$ & $85.019\left(2.20^{* *}\right)$ \\
\hline \multicolumn{4}{|l|}{ spring_temp } \\
\hline summer_tempsq & $-5.848(-2.42 * *)$ & $-3.265(-1.18)$ & $8.411(7.24 * * *)$ \\
\hline autum_tempsq & $\left.7.477\left(2.61^{* *}\right)\right)$ & $6.778(2.04 * *)$ & $-9.623(-3.10 * * *)$ \\
\hline winter_tempsq & $-12.267(-1.58)$ & $-8.639(-0.08)$ & $-2.147\left(-2.15^{* *}\right)$ \\
\hline spring_tempsq & $15.776(1.62 *)$ & $19.393(1.62)$ & $2.977\left(4.49^{* *}\right)$ \\
\hline summer_precip & $302.463(2.43 * *)$ & $190.208\left(2.11^{* *}\right)$ & $152.629\left(9.68^{* * *}\right)$ \\
\hline autum_precip & $-3.468\left(-2.33^{* *}\right)$ & $-4.022(-2.21 * *)$ & \\
\hline \multicolumn{4}{|l|}{ winter_precip } \\
\hline \multicolumn{4}{|l|}{ spring_precip } \\
\hline summer_precipsq & $-0.527(2.39 * *)$ & $-4.453\left(-1.76^{*}\right)$ & $-0.127(-3.72 * * *)$ \\
\hline autum_precipsq & $-9.339\left(-2.26^{* *}\right)$ & $-12.046(-2.04 * *)$ & $11.657(3.22 * * *)$ \\
\hline winter_precipsq & $-3.089(-2.52 * *)$ & $-4.021\left(-2.48^{* *}\right)$ & $-6.562(-2.99 * * *)$ \\
\hline spring_precipsq & $1.155(2.54 * *)$ & $14.942(2.49 * *)$ & $2.728(4.49 * * *)$ \\
\hline perci & $-764.926\left(-1.87^{*}\right)$ & $-931.392(-2.31 * *)$ & \\
\hline perclcFU & $398.782\left(2.58^{* *}\right)$ & $547.656\left(2.66^{* *}\right)$ & $707.480(8.12 * * *)$ \\
\hline perclfCU & $455.769\left(2.29^{* *}\right)$ & $2614.327(0.94)$ & \\
\hline perclgCU & $1937.239\left(3.36^{* * *}\right)$ & $1122.622\left(1.68^{*}\right)$ & \\
\hline percC_qc1 1a & $256.398\left(2.53^{* *}\right)$ & $365.951\left(2.65^{* *}\right)$ & \\
\hline Population_density & $1.237(1.64 *)$ & $-3.950(-1.83 *)$ & $-11.312(-3.54 * * *)$ \\
\hline Extension_contact & $144.135\left(2.21^{* *}\right)$ & $379.417\left(2.55^{* *}\right)$ & $-601.9364\left(-5.66^{* * *}\right)$ \\
\hline Household_size & $25.436\left(2.45^{* *}\right)$ & $12.130(0.97)$ & $53.479\left(5.60^{* * *}\right)$ \\
\hline Education_years_head & $13.588\left(2.53^{* *}\right)$ & $14.144\left(2.26^{* *}\right)$ & $30.484\left(5.79^{* * *}\right)$ \\
\hline Total_cropped_area & $-85.518(-11.18 * * *)$ & $-90.462(-9.90 * * *)$ & $-59.185(-6.80 * * *)$ \\
\hline Distance_capital & $-4.567\left(-2.13^{* *}\right)$ & $-9.321(-1.79 *)$ & $-13.853(-2.96 * *)$ \\
\hline Livestock_index & $4.328(7.67 * * *)$ & $5.145(6.34 * * *)$ & $3.260(7.71 * * *)$ \\
\hline Irrigation $(1 / 0)$ & $107.345(1.97 *)$ & & \\
\hline $\begin{array}{l}\text { Runoff_mean } \\
\text { Pseudo R2 }\end{array}$ & $\begin{array}{c}141.739\left(2.59^{* * *}\right) \\
\mathbf{0 . 1 8 7 1}\end{array}$ & $\begin{array}{c}-117.453\left(-1.98^{*}\right) \\
\mathbf{0 . 2 3 1 2}\end{array}$ & $\begin{array}{c}194.050\left(2.66^{* *}\right) \\
\mathbf{0 . 2 4 5 8}\end{array}$ \\
\hline Number of observations & 500 & 377 & 123 \\
\hline
\end{tabular}

$*$ significant at $10 \%$ level $* *$ significant at $5 \%$ level $* * *$ significant at $1 \%$ level 
Table 9: Marginal effects of seasonal temperature and precipitation on net revenue

\begin{tabular}{lccc}
\hline Season & All farms regression & Dry land regression & Irrigated regression \\
\hline Temperature & & & \\
Summer & $-86.34 * *(-4.82)$ & $-98.63 * *(-7.26)$ & $-76.74 * *(-3.79)$ \\
Autumn & $39.05 * *(2.26)$ & $32.39 * * *(2.19)$ & $43.28^{*}(1.74)$ \\
Winter & $34.08^{* * *}(1.58)$ & $45.44 * *(2.47)$ & $69.04 * *(2.22)$ \\
Spring & $-44.13 *(-2.63)$ & $-50.36 *(-3.51)$ & $-55.24 *(2.28)$ \\
\hline Precipitation & & & \\
Summer & $39.54 * *(15.37)$ & $31.29 * *(12.16)$ & $25.21 * * *(9.81)$ \\
Autumn & $30.90 * *(7.76)$ & $22.23 * *(5.58)$ & $21.80 *(5.47)$ \\
Winter & $23.07 *(0.48)$ & $24.30^{* *}(0.51)$ & $20.74 *(0.43)$ \\
Spring & $37.80(1.64)$ & $31.76 *(1.38)$ & $34.33 *(-1.49)$ \\
\hline
\end{tabular}

$*$ significant at $10 \%$ level $* *$ significant at $5 \%$ level $* * *$ significant at $1 \%$ level

Note: The numbers in brackets represent the elasticities.

Table 10: Forecasted impacts on net farm revenue from uniform climate scenarios

\begin{tabular}{lccc}
\hline Climate change scenarios & All farms & Dry land & Irrigated \\
\hline$+\mathbf{2 . 5}{ }^{\circ} \mathrm{C}$ increase in temperature & & & \\
$\Delta$ Net revenue (US\$ per ha) & $-109.93(-31 \%)$ & $-117.42(-17 \%)$ & $96.61(3 \%)$ \\
$\Delta$ Total net revenue (billions US\$) & -0.368 & -0.373 & 0.017 \\
\hline$+\mathbf{5}^{\circ} \mathrm{C}$ increase in temperature & $-128.84(-36 \%)$ & $-145.50(21 \%)$ & $-16.78(-1 \%)$ \\
$\Delta$ Net revenue (US\$ per ha) & -0.432 & -0.462 & -0.003 \\
$\Delta$ Total net revenue (billions US\$) & $-99.18(-27 \%)$ & $-112.35(-16 \%)$ & $-53.82(-2 \%)$ \\
\hline $\mathbf{7 \%}$ reduction in rainfall & -0.332 & -0.357 & -0.009 \\
$\Delta$ Net revenue (US\$ per ha) & $-101.97(-28 \%)$ & $-148.33(-22 \%)$ & $-77.63(-2 \%)$ \\
$\Delta$ Total net revenue (billions US\$) & -0.342 & -0.471 & -0.014 \\
\hline $\mathbf{1 4 \%}$ reduction in rainfall & & & \\
$\Delta$ Net revenue (US\$ per ha) & & & \\
$\Delta$ Total net revenue (billions US\$) & & & \\
\hline
\end{tabular}

Note: Using coefficients in Table 6 and uniform climate changes. The numbers in brackets represent the percentage change in net farm revenue per hectare relative to the mean of the sample. 
Table 11: Climate predictions of SRES Models for 2050 and 2100

\begin{tabular}{lcccc}
\hline Model & & Current & $\mathbf{2 0 5 0}$ & $\mathbf{2 1 0 0}$ \\
\hline CGM2 & & 23.34 & 26.81 & 27.00 \\
HadCM3 & Temperature & 23.34 & 27.22 & 27.82 \\
PCM & & 23.34 & 25.88 & 25.20 \\
\hline CGM2 & & 61.77 & 60.67 & 56.18 \\
HadCM3 & Precipitation & 61.77 & 51.55 & 50.62 \\
PCM & & 61.77 & 50.99 & 49.44 \\
\hline
\end{tabular}

Table 12: Forecasted impacts on net farm revenue from SRES climate scenarios

\begin{tabular}{|c|c|c|c|c|c|c|}
\hline Scenario & $\begin{array}{c}\text { CGM2 } \\
2050\end{array}$ & $\begin{array}{c}\text { CGM2 } \\
2100\end{array}$ & $\begin{array}{c}\text { HadCM3 } \\
2050\end{array}$ & $\begin{array}{c}\text { HadCM3 } \\
2100\end{array}$ & $\begin{array}{l}\text { PCM } \\
2050\end{array}$ & $\begin{array}{l}\text { PCM } \\
2100\end{array}$ \\
\hline \multicolumn{7}{|l|}{ All farms } \\
\hline $\begin{array}{l}\Delta \text { Net revenue } \\
\text { (US\$ per ha) }\end{array}$ & $\begin{array}{l}-135.46 \\
(-38 \%)\end{array}$ & $\begin{array}{l}-248.07 \\
(-70 \%)\end{array}$ & $\begin{array}{l}-322.58 \\
(-91 \%)\end{array}$ & $\begin{array}{l}-388.39 \\
(-109 \%)\end{array}$ & $\begin{array}{l}-287.82 \\
(-81 \%)\end{array}$ & $\begin{array}{l}-423.52 \\
(-119 \%)\end{array}$ \\
\hline $\begin{array}{l}\Delta \text { Total net revenue } \\
\text { (billions US\$) }\end{array}$ & -0.45 & -0.83 & -1.08 & -1.30 & -0.96 & -1.42 \\
\hline \multicolumn{7}{|l|}{ Dry land } \\
\hline & $\begin{array}{l}-201.41 \\
(-39 \%)\end{array}$ & $\begin{array}{l}-333.90 \\
(-65 \%)\end{array}$ & $\begin{array}{l}-367.39 \\
(-71 \%)\end{array}$ & $\begin{array}{l}-480.43 \\
(-93 \%)\end{array}$ & $\begin{array}{c}-346.73 \\
(67 \%)\end{array}$ & $\begin{array}{l}-434.01 \\
(-84 \%)\end{array}$ \\
\hline $\begin{array}{l}\Delta \text { Total net revenue } \\
\text { (billions US\$) }\end{array}$ & -0.64 & -1.06 & -1.17 & -1.53 & -1.10 & -1.38 \\
\hline \multicolumn{7}{|l|}{ Irrigated } \\
\hline & $\begin{array}{l}-43.32 \\
(-8 \%)\end{array}$ & $\begin{array}{l}-155.87 \\
(-30 \%)\end{array}$ & $\begin{array}{l}-222.96 \\
(-43 \%)\end{array}$ & $\begin{array}{l}-227.69 \\
(-44 \%)\end{array}$ & $\begin{array}{l}-216.03 \\
(-42 \%)\end{array}$ & $\begin{array}{l}-242.49 \\
(-47 \%)\end{array}$ \\
\hline $\begin{array}{l}\Delta \text { Total net revenue } \\
\text { (billions US\$) }\end{array}$ & -0.01 & -0.03 & -0.04 & -0.04 & -0.04 & -0.04 \\
\hline
\end{tabular}

Note: Using coefficients in Table 6 and SRES climate scenarios. The numbers in brackets represent the percentage change in net farm revenue per hectare relative to the mean of the sample. 


\section{Climate Change in Zimbabwe}
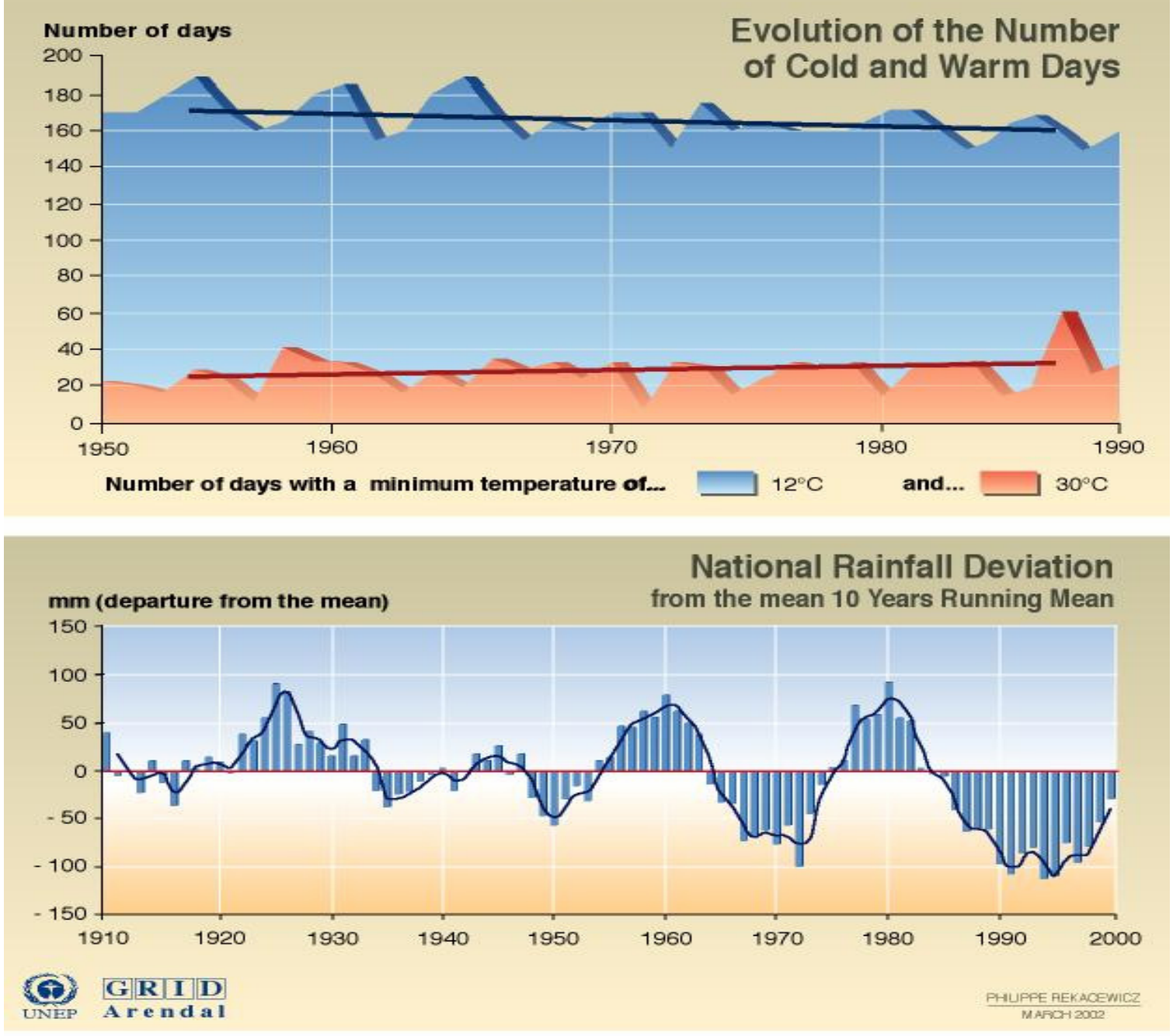

Source: Zimbabwe Department of Meteorological Service at http://weather.utande.co.zW/climate/climatechange.htm

Figure 1: Long-term trends in temperature and rainfall in Zimbabwe: 1910-2000 


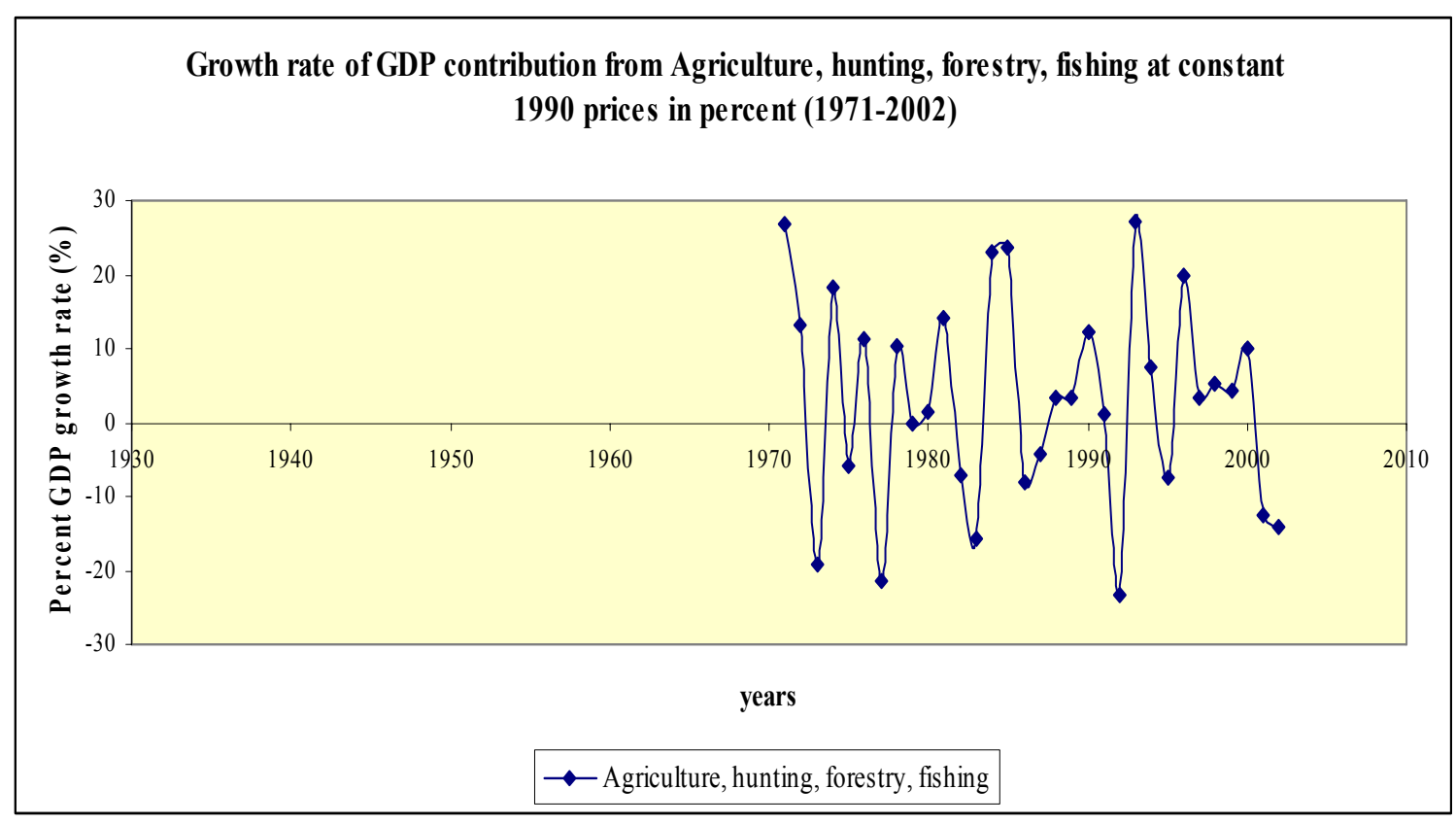

Figure 2: Growth rate of GDP contribution from agriculture, hunting, forestry and fishing

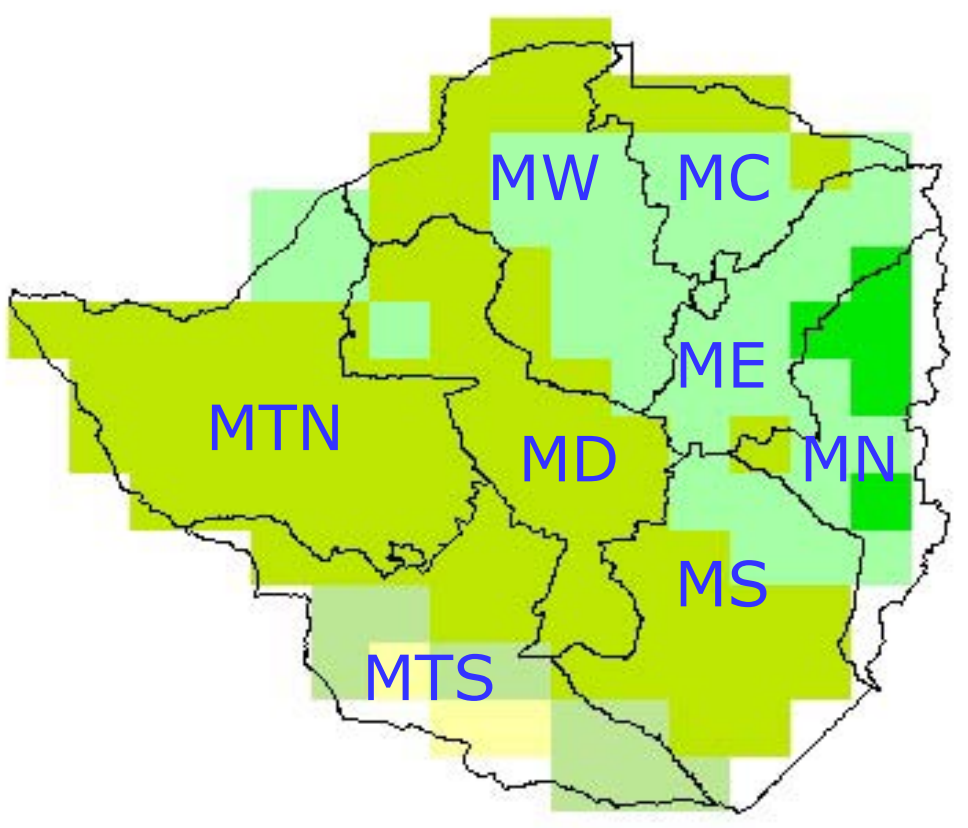

\begin{tabular}{lrr}
\hline Province & $\begin{array}{c}\text { No. of } \\
\text { surveyed } \\
\text { districts }\end{array}$ & $\begin{array}{c}\text { Households } \\
\text { sampled }\end{array}$ \\
\hline 1. Mashonaland East (ME) & 3 & 61 \\
2. Mashonaland Central MC) & 2 & 59 \\
3. Mashonaland West (MW) & 4 & 154 \\
4. Manicaland (MN) & 4 & 153 \\
5. Masvingo (MS) & 5 & 141 \\
6. Midlands MD) & 4 & 132 \\
Total & 22 & 700 \\
\hline
\end{tabular}

Figure 3: Summary of survey areas and number of households interviewed 


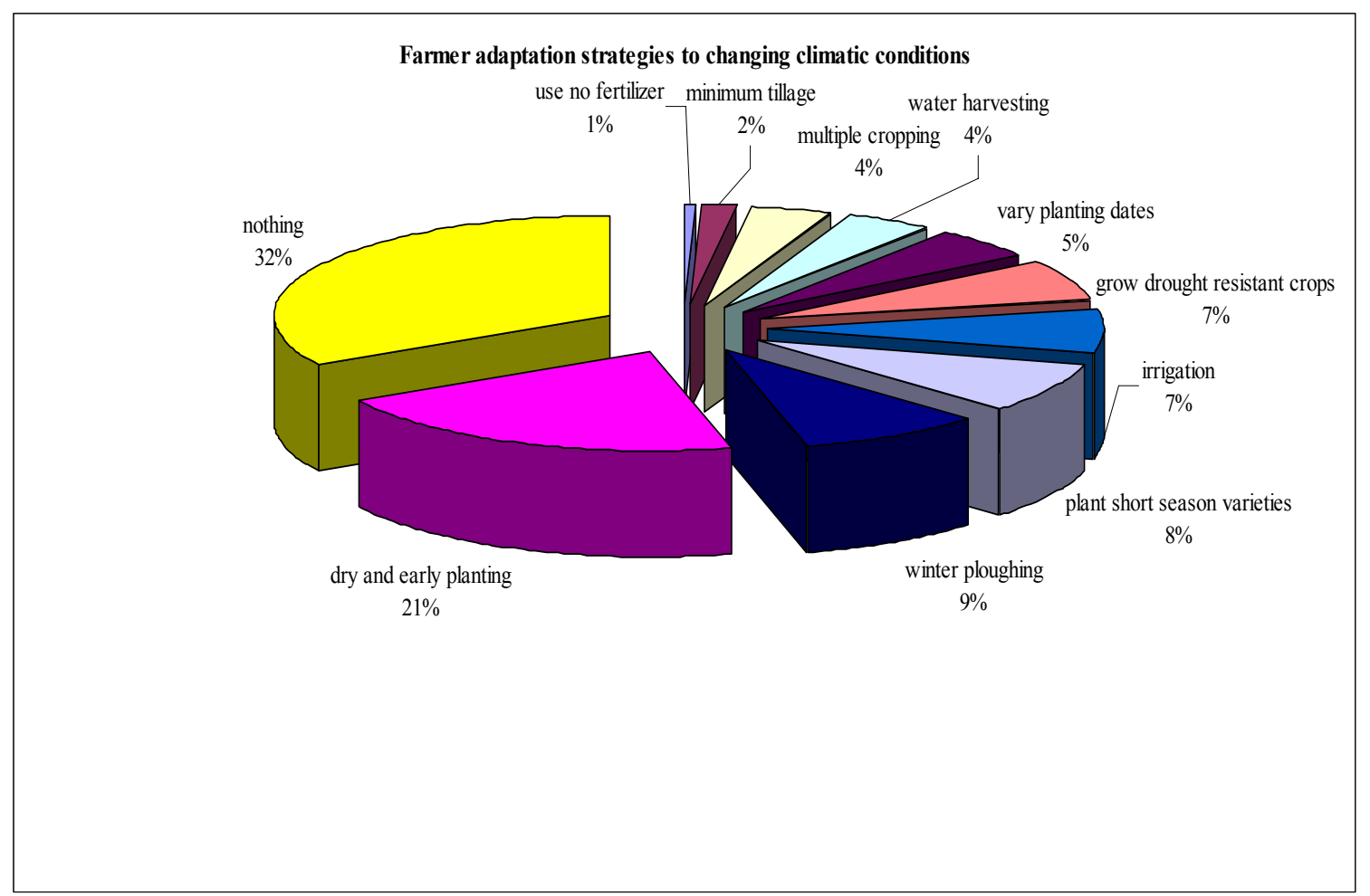

Figure 4: Farmer adaptation strategies to changing climatic conditions in Zimbabwe 



\section{Policy Research Working Paper Series}

Title

WPS4263 HIVIAIDS and Social Capital in a Cross-Section of Countries

WPS4264 Financing of the Private Sector in Mexico, 2000-05: Evolution, Composition, and Determinants

WPS4265 The Structure of Import Tariffs in the Russian Federation: 2001-05

WPS4266 The Economic Community of West African States: Fiscal Revenue Implications of the Prospective Economic Partnership Agreement with the European Union

WPS4267 Financial Intermediation in the Pre-Consolicated Banking Sector in Nigeria

WPS4268 Power to the People: Evidence from a Randomized Field Experiment of a Community-Based Monitoring Project in Uganda

WPS4269 Shadow Sovereign Ratings for Unrated Developing Countries

WPS4270 Jump-Starting Self-Employment? Evidence among Welfare Participants in Argentina

WPS4271 Construction, Corruption, and Developing Countries

WPS4272 Migration, Remittances, Poverty, and Human Capital: Conceptual and Empirical Challenges

WPS4273 Rules of Origin and the Web of East Asian Free Trade Agreements

WPS4274 Are Labor Regulations Driving Computer Usage in India's Retail Stores?

WPS4275 Can Foreign Lobbying Enhance Development? The Case of Tourism in the Caribbean

WPS4276 Human Capital, Trade Liberalization, and Income Risk

WPS4277 Climate Change Adaptation in Africa: A Microeconomic Analysis of Livestock Choice

WPS4278 Endogenous Irrigation: The Impact of Climate Change on Farmers in Africa

WPS4279 The Impact of Climate Change on Livestock Management in Africa: A Structural Ricardian Analysis
Author

Date

\section{Contact for paper}

Antonio C. David

June 2007

A. David

82842

Constantinos Stephanou

June 2007

S. Coca

Emanuel Salinas Muñoz

37474

Oleksandr Shepotylo

June 2007

P. Flewitt 32724

Simplice G. Zouhon-Bi June 2007

S. Zouhon-Bi Lynge Nielsen 82929

Heiko Hesse

June 2007

G. Johnson 34436

Martina Björkman

June 2007

I. Hafiz

Jakob Svensson

Dilip Ratha

June 2007

N. Aliyeva

80524

Sanket Mohapatra

Rita Almeida

June 2007

A. Bonfield 31248

Charles Kenny

June 2007

C. Kenny 33540

David McKenzie

July 2007

M. Sasin

36877

Miriam Manchin

July 2007

Annette O. Pelkmans-Balaoing

Mohammad Amin

July 2007

L. Yeargin

81553

S. Narsiah 88768

Kishore Gawande

July 2007

V. Cornago

William Maloney

Gabriel V. Montes Rojas

Tom Krebs

July 2007

V. Cornago

Pravin Krishna

William Maloney

Sungno Niggol Seo

July 2007

P. Kokila

Robert Mendelsohn

Pradeep Kurukulasuriya July 2007

Robert Mendelsohn

Sungno Niggol Seo

Robert Mendelsohn
33716

P. Kokila

33716

July 2007

P. Kokila 33716 
Policy Research Working Paper Series

Title

WPS4280 Governance Matters VI: Aggregate and Individual Governance: Indicators, 1996-2006

WPS4281 Credit Growth In Emerging Europe: A Cause For Stability Concerns?

WPS4282 Are Cash Transfers Made to Women Spent Like Other Sources of Income

WPS4283 Innovation Shortfalls

WPS4284 Customer Market Power and the Provision of Trade Credit: Evidence from Eastern Europe and Central Asia

WPS4285 Poverty Analysis Using An International Cross-Country Demand System

WPS4286 Institutional Effects as Determinants of Learning Outcomes: Exploring State Variations in Mexico

WPS4287 A Cross-Country Analysis of Public Debt Management Strategies

WPS4288 Actual Crop Water Use in Project Countries A Synthesis at the Regional Level

WPS4289 Sensitivity of Cropping Patterns in Africa to Transient Climate Change

WPS4290 The Impacts of Climate Change on Regional Water Resources and Agriculture in Africa

WPS4291 An Empirical Economic AssessmentOf Impacts Of Climate Change On Agriculture In Zambia
Author

Daniel Kaufmann

Aart Kraay

Massimo Mastruzzi

Sophie Sirtaine

Ilias Skamnelos

Norbert Schady

José Rosero

William Maloney

Andrés Rodríguez-Clare

Neeltje Van Horen

July 2007

July 2007

. A. L. Cranfield

Paul V. Preckel

Thomas W. Hertel

Jesús Álvarez

Vicente García Moreno

Harry Anthony Patrinos

Martin Meleckyy

Robina Wahaj

Florent Maraux

Giovanni Munoz

Alexander Lotsch

Kenneth Strzepek

Alyssa McCluskey

Suman Jain

July 2007

July 2007

July 2007

July 2007

July 2007

July 2007

July 2007

July 2007

July 2007

\section{Contact for paper}

R. Bonfield 31248

S. Sirtaine 87006

I. Hafiz 37851

V. Cornago 84039

M. Gamboa 34847

S. Baksh 31085

M. Rosenquist 82602

P. Kokila 33716

P. Kokila 33716

P. Kokila 33716

P. Kokila 33716 